\title{
Strain-dependent embryonic lethality and exaggerated vascular remodeling in heparin cofactor II-deficient mice
}

\author{
Ken-ichi Aihara, ${ }^{1,2,3}$ Hiroyuki Azuma, ${ }^{1}$ Masashi Akaike, ${ }^{1}$ Yasumasa Ikeda, ${ }^{1,2}$ \\ Masataka Sata, ${ }^{4}$ Nobuyuki Takamori, ${ }^{1}$ Shusuke Yagi, ${ }^{1}$ Takashi Iwase, ${ }^{1}$ Yuka Sumitomo, ${ }^{1}$ \\ Hirotaka Kawano,, ${ }^{3}$ Takashi Yamada, ${ }^{3}$ Toru Fukuda, ${ }^{3}$ Takahiro Matsumoto, ${ }^{3,5}$ Keisuke Sekine, ${ }^{3}$ \\ Takashi Sato, ${ }^{3}$ Yuko Nakamichi, ${ }^{3}$ Yoko Yamamoto, ${ }^{3}$ Kimihiro Yoshimura, ${ }^{3}$ \\ Tomoyuki Watanabe, ${ }^{3}$ Takashi Nakamura, ${ }^{3}$ Akimasa Oomizu, 6 Minoru Tsukada, ${ }^{6}$ \\ Hideki Hayashi,7 Toshiki Sudo,7 Shigeaki Kato, ${ }^{3,5}$ and Toshio Matsumoto,,2 \\ ${ }^{1}$ Department of Medicine and Bioregulatory Sciences and 221 st Century Center of Excellence Program, The University of Tokushima \\ Graduate School of Health Biosciences, Tokushima, Japan. 3institute of Molecular and Cellular Biosciences and \\ ${ }^{4}$ Department of Cardiovascular Medicine, The University of Tokyo, Tokyo, Japan. ${ }^{5}$ ERATO, Japan Science and Technology Agency, Saitama, Japan. \\ ${ }^{6}$ Benesis Corp., Osaka, Japan. ${ }^{7}$ First Institute of New Drug Discovery, Otsuka Pharmaceutical Co., Tokushima, Japan.
}

\begin{abstract}
Heparin cofactor II (HCII) specifically inhibits thrombin action at sites of injured arterial wall, and patients with HCII deficiency exhibit advanced atherosclerosis. However, the in vivo effects and the molecular mechanism underlying the action of HCII during vascular remodeling remain elusive. To clarify the role of HCII in vascular remodeling, we generated $H C I I$-deficient mice by gene targeting. In contrast to a previous report, $\mathrm{HCII}^{-/-}$mice were embryonically lethal. In $\mathrm{HCII}^{+/-}$mice, prominent intimal hyperplasia with increased cellular proliferation was observed after tube cuff and wire vascular injury. The number of protease-activated receptor-1-positive (PAR-1-positive) cells was increased in the thickened vascular wall of $\mathrm{HCII}^{+/-}$mice, suggesting enhanced thrombin action in this region. Cuff injury also increased the expression levels of inflammatory cytokines and chemokines in the vascular wall of $\mathrm{HCII}^{+/-}$mice. The intimal hyperplasia in $\mathrm{HCII}^{+/-}$mice with vascular injury was abrogated by human $\mathrm{HCII}$ supplementation. Furthermore, HCII deficiency caused acceleration of aortic plaque formation with increased PAR-1 expression and oxidative stress in apoE-KO mice. These results demonstrate that HCII protects against thrombin-induced remodeling of an injured vascular wall by inhibiting thrombin action and suggest that $\mathrm{HCII}$ is potentially therapeutic against atherosclerosis without causing coagulatory disturbance.
\end{abstract}

\section{Introduction}

Thrombin not only acts as a key enzyme in the formation of fibrin clots during the blood coagulation process but also activates platelets, vascular endothelial cells, VSMCs, macrophages, and fibroblasts to enhance procoagulation (1), chemoattraction (2), mitogenesis (3), and proliferation (4) of these cells. Actions of thrombin in these cells are mediated through proteolytic processing of specific cell-surface receptors known as protease-activated receptors (PARs) (5). Among the 4 members of the family of PARs, PAR-1 is known as the most important thrombin receptor. Although approximately one-half of PAR-1-deficient mice are embryonically lethal (6), mice that survive manifest diminished neointimal hyperplasia after arterial injury compared with WT mice (7). In humans, PAR-1 is widely expressed in macrophages, VSMCs, and intimal cells of atherosclerotic lesions (8), and PAR-1 activation has been shown to play an important role in the development of cardiovascular diseases, including arterial thrombosis (9), stroke, and ischemic heart disease $(10,11)$. In addition, it has

Nonstandard abbreviations used: AT, antithrombin; DHE, dihydroethidium; DS, dermatan sulfate; Egr-1, early growth response protein-1; HCII, heparin cofactor II; KLF5, Krüppel-like zinc finger transcription factor 5; MCP-1, monocyte chemoattractant protein-1; $8 \mathrm{OHdG}, 8$-hydroxy-2'-deoxyguanosine; PCNA, proliferating cell nuclear antigen.

Conflict of interest: The authors have declared that no conflict of interest exists. Citation for this article: J. Clin. Invest. 117:1514-1526 (2007). doi:10.1172/JCI27095 been reported that thrombogenicity-regulating factors such as tissue factor (TF), thrombomodulin (TM), hirudin, vitronectin, and plasminogen activator inhibitor-1 (PAI-1) regulate VSMC proliferation or migration leading to vascular remodeling (12-15). Those factors directly or indirectly contribute to modulation of thrombin action. Thrombin action-accelerating factors, including $\mathrm{TF}$, vitronectin, and PAI-1, promote vascular remodeling, whereas thrombin action-attenuating factors such as TM and hirudin suppress vascular remodeling (12-15).

Enhanced thrombin action at sites of injured vascular endothelium is efficiently inhibited by antithrombin (AT) and heparin cofactor II (HCII). AT exhibits its activity by binding to heparan sulfate, and anticoagulatory active heparan sulfate proteoglycans are concentrated immediately beneath the aortic endothelium, with only a small amount present on the luminal surfaces of endothelial cells (16). HCII is also a serine protease inhibitor (serpin) with a molecular weight of $65.6 \mathrm{kDa}$. HCII is synthesized by hepatocytes and secreted into the blood stream at a concentration of about $1.0 \mu \mathrm{mol} / 1$ (17) and is distributed in the intima and media of atherosclerotic lesions as well as walls of normal arteries. HCII inactivates thrombin without affecting other proteases involved in the blood coagulation cascade. Inactivation of thrombin action by HCII is enhanced by more than 1,000-fold after binding to dermatan sulfate (DS) $(17,18)$, which is synthesized and secreted by smooth muscle cells and fibroblasts and is deposited in the matrix 
A

WT
HCIl locus

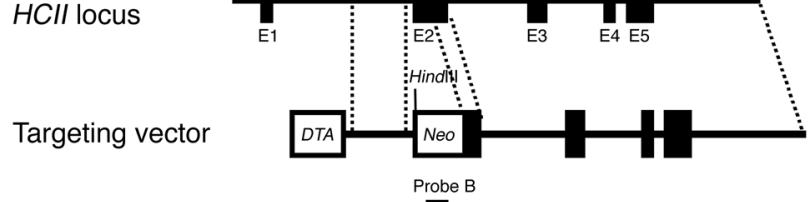

Mutant

HCIl locus

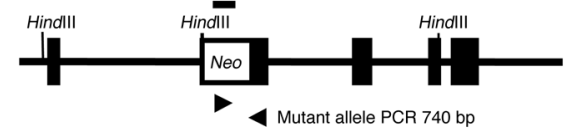

Hind III digestion

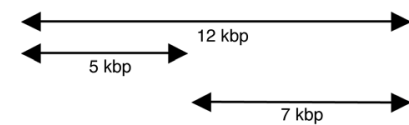

(+) Probe A

(+) Probe B
C

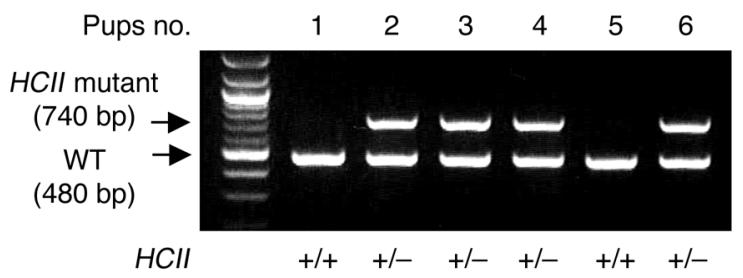

B

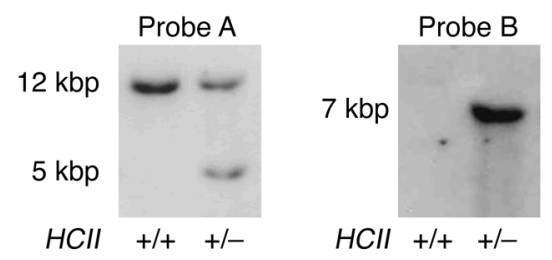

D

$\mathrm{HCll}^{+/-}$male

\begin{tabular}{|c|c|c|c|c|c|}
\hline 11 & $\hat{i} \hat{i}$ & 71 & 11 & 11 & \\
\hline 1 & 2 & 3 & 4 & 5 & \\
\hline 11 & 11 & 11 & 11 & 11 & \\
\hline 5 & 6 & 7 & 8 & 9 & \\
\hline 11 & 11 & 11 & 11 & it & \\
\hline 10 & 11 & 12 & 13 & 14 & \\
\hline 11 & $B D$ & 11 & is & 1 & 1 \\
\hline 15 & 16 & 17 & 18 & $x$ & $Y$ \\
\hline
\end{tabular}

$\mathrm{HCll}^{+/-}$female

\begin{tabular}{|cccccc|}
\hline$\|$ & $3 \mid$ & $\|$ & $\|$ & $\|$ & \\
1 & 2 & 3 & 4 & 5 & \\
$\|$ & $\|$ & $\|$ & $\|$ & $\| !$ & \\
5 & 6 & 7 & 8 & 9 & \\
$\|$ & $\|$ & $\|$ & $\|$ & $\| !$ & \\
10 & 11 & 12 & 13 & 14 & \\
$\|$ & $\| 1$ & $\|$ & $\mathbf{H}$ & $\|$ & \\
15 & 16 & 17 & 18 & $x$ & $y$ \\
\hline
\end{tabular}

Figure 1

Targeted disruption of murine $\mathrm{HCll}$ gene, genotyping, and karyotypes of $\mathrm{HCll}$-mutant mice. (A) Genomic locus, targeting vector, and predicted targeting locus are illustrated. External (probe A) and internal (probe B) probes were used for Southern blot analysis. Two sets of PCR primers for detecting the 480-bp WT allele and 740-bp mutant allele were employed for genotyping. (B) Southern blot analysis of murine genomic DNA. A 5-kbp HindIII fragment denotes the homologous recombinant allele in probe A as an external probe, and a single 7-kbp HindIII fragment denotes the homologous recombinant allele without random integration in probe B as an internal probe. (C) Genotyping PCR. The mutant allele yielded a 740-bp band, and the WT allele yielded a 480-bp band. (D) Karyotype analysis of $\mathrm{HCll}^{+/-}$male and female mice. Chromosomes of splenic lymphocytes in both male and female $\mathrm{HCll}$ mutant mice showed normal karyotypes.

of vascular intima and media (19-21). Thus, AT inhibits thrombin action and elicits an anticoagulatory effect at the surface of the vascular wall, whereas HCII can most efficiently act in the intima and media of the vascular wall to protect them from the actions of thrombin on vascular remodeling.

We previously reported a 66-year-old woman with type I congenital HCII deficiency manifesting multiple atherosclerotic lesions, including multiple coronary vessel disease, bilateral carotid stenosis, right renal artery stenosis, and abdominal aortic aneurysm (22). The advanced atherosclerotic lesions in this patient as well as in another family member prompted us to speculate that HCII plays a protective role against the formation of atherosclerotic lesions in elderly individuals who have cardiovascular risk factors with injured vascular walls. We therefore conducted 2 clinical studies to determine the relationship between plasma HCII activity and development of atherosclerotic lesions. Studies on in-stent restenosis after percutaneous coronary intervention (23) and on carotid atherosclerosis (24) provided clinical evidence that HCII plays a protective role against the progression of atherosclerosis in the elderly with atherosclerotic risk factors. In 2002, He et al. generated HCII gene-KO mice and showed that the $\mathrm{KO}$ mice manifest normal growth and enhanced thrombogenicity after photochemical damage to the carotid endothelium (25). However, the mechanisms of HCII action as well as the importance of HCII in preventing the formation of atherosclerotic lesions are as yet unclear. To address these issues, we generated HCII-deficient mice by gene targeting and analyzed vascular remodeling in WT and HCII-mutant mice using a vascular injury model and a hyperlipidemia-induced atherosclerosis model.

\section{Results}

Generation and characterization of HCII-KO mice. In order to disrupt the HCII gene function, we deleted a 120-bp fragment of exon 2 including the ATG site in the HCII gene and inserted a phosphoglycerate kinase-neomycin cassette with polyA termination. The targeting vector (Figure 1A) was introduced into TT2 ES cells by electroporation. Among 354 ES clones, we found 3 clones with mutated HCII exon 2 by homologous recombination, which was confirmed by Southern blot analysis with external and internal probes (Figure 1B). Two of the 3 clones did not have any random integration (Figure 1B). Blastocyst injections of 2 independent ES clones yielded chimeric mice. The chimeric mice derived from $1 \mathrm{ES}$ clone transmitted the mutant allele into the germ line. $\mathrm{HCII}^{+/-}$mice were produced by mating the chimeric mice with female C57BL/6J mice. Thereafter, $\mathrm{HCII}^{+/-}$mice were backcrossed for 10 generations with the C57BL/6J strain. By mating with male and female $\mathrm{HCII}^{+/-}$mice, we could not obtain $\mathrm{HCII}^{-/-}$mice due to early embryonic lethality at E6.5 to E8.5 (Table 1 and Figure 1C); however, $\mathrm{HCII}^{+/-}$mice were fertile and exhibited normal survival and growth (data not shown). $\mathrm{G}$ band staining demonstrated that male $\mathrm{HCII}^{+-}$mice and female 


\section{Table 1}

Genotypes of embryos and newborns derived through timed mating of $\mathrm{HCll}$-mutant heterozygote

\begin{tabular}{lcccc} 
Days of gestation & \multicolumn{3}{c}{ Genotype of $H \boldsymbol{C l l}$ gene } & Total \\
& $+/+$ & $+/-$ & $-/-$ & \\
Newborn & 88 & 177 & 0 & 265 \\
16.5 & 23 & 49 & 0 & 72 \\
14.5 & 12 & 20 & 0 & 32 \\
12.5 & 10 & 22 & 0 & 32 \\
10.5 & 9 & 21 & 0 & 30 \\
8.5 & 6 & 10 & 0 & 16
\end{tabular}

$\mathrm{HCII}^{+/-}$mice have 38,XY karyotype and 38,XX karyotype, respectively, with no obvious abnormal chromosomes (Figure 1D). FISH analysis using a phosphoglycerate kinase-neomycin cassette probe showed the expected position of the phosphoglycerate kinase-neomycin cassette at the sixteenth murine chromosome, and no random integration of the cassette was observed in male and female $\mathrm{HCII}^{+/-}$ mice (Figure 2A). In addition, the expression levels of neighboring genes around the HCII genome, such as Ube2l3, Pik4ca, and Snap29, were the same in $\mathrm{HCII}^{+/+}$and $\mathrm{HCII}^{+/-}$mice (Figure 2B). Conventional RT-PCR analysis of the full-length $H C I I$ gene demonstrated no abnormal bands in either $\mathrm{HCII}^{+/+}$or $\mathrm{HCII}^{+-}$mice (Figure 3A), and direct sequence analysis of each PCR product revealed no mutations in either $\mathrm{HCII}^{+/+}$or $\mathrm{HCII}^{+/-}$mice (data not shown). These results confirmed the absence of truncated HCII transcripts and noninterference for mRNA levels of neighboring genes around the HCII genome after HCII targeting vector introduction. $\mathrm{HCII}^{+/-}$mice showed half of the level of HCII protein content and mRNA in the liver and about $60 \%$ of the plasma $\mathrm{HCII}$ activity of $\mathrm{HCII}^{+/+}$mice (Figure 3, B-D). To clarify the difference between embryonic lethality of HCII mutant mice in the study by He et al. (25) (their heterozygous $\mathrm{HCII}$ mutant mice are designated " $\mathrm{HCII}^{+/-}$St. Louis" herein) and that of our HCII mutant mice (our heterozygous HCII mutant mice are designated " $\mathrm{HCII}^{+/-}$Tokushima" herein), we interbred $\mathrm{HCII}^{+/-}$Tokushima with $\mathrm{HCII}^{+/-}$ St. Louis mice. HCII homozygous mutant pups having different HCII mutant alleles (Tokushima/St. Louis) were born close to the expected mendelian frequency (Table 2). Although the HCII (Tokushima/St. Louis) homozygous mutant mice showed undetectable plasma HCII antigen levels, the mutant mice exhibited $14.2 \% \pm 2 \%$ of plasma HCII activities (Table 2). We conducted all the following examinations using $\mathrm{HCII}^{+/}$- Tokushima mice.

Enhanced platelet aggregation in $\mathrm{HCII}^{+/-}$mice. Hemostatic examinations, including examinations of plasma fibrinogen level, prothrombin time, and plasma AT activity, revealed no significant differences between $\mathrm{HCII}^{+/+}$and $\mathrm{HCII}^{+/-}$mice (Figure 4A). Next, we evaluated ADP-induced whole blood aggregation using a screen filtration pressure method in these mice. Platelet aggregatory threshold index values in $\mathrm{HCII}^{+/-}$mice were decreased markedly compared with those in $\mathrm{HCII}^{+/+}$mice (Figure 4B). These results indicate that enhanced platelet aggregation occurred in $\mathrm{HCII}^{+-}$mice and suggest that HCII has a suppressive effect on platelet aggregability in vivo.
Arterial cuff injury causes enhanced intimal and adventitial byperplasia in $\mathrm{HCII}^{+/-}$mice. No morphometrical differences were observed between uninjured femoral arteries in WT and $\mathrm{HCII}^{+/-}$mice (Figure 5, A and B). In an attempt to determine whether $\mathrm{HCII}^{+/-}$ mice exhibit a difference in structure of the vascular wall after vascular injury, we compared structural changes in the walls of arteries after polyethylene tube cuff placement for 4 weeks. Cuffinjured femoral arteries in $\mathrm{HCII}^{+/}$- mice revealed a prominent increase in intimal and adventitial areas but not in the medial area compared with those in $\mathrm{HCII}^{+/+}$mice (Figure 5, A and $\mathrm{B}$ ). As a consequence, the intima/media ratio and adventitia/media ratio were also significantly increased in $\mathrm{HCII}^{+/-}$compared with $\mathrm{HCII}^{+/+}$mice (Figure 5, A and B).

Augmentation of cell proliferation in vascular walls of cuff-injured $\mathrm{HCII}^{+/-}$mice. To identify and quantify proliferating vascular mesenchymal cells in these lesions, we performed proliferating cell nuclear antigen (PCNA) and BrdU staining. There were only a few positive nuclei for PCNA and BrdU staining at intima and media in both uninjured $\mathrm{HCII}^{+/+}$and $\mathrm{HCII}^{+/-}$mice (Figure 6, A-D). Although there was a marked increase in the number of PCNAand BrdU-positive cells in both $\mathrm{HCII}^{+/+}$and $\mathrm{HCII}^{+/-}$mice after cuff injury, a much greater increase in PCNA- and BrdU-stained cells was observed in cuff-injured $\mathrm{HCII}^{+/-}$mice than in $\mathrm{HCII}^{+/+}$mice (Figure 6, A-D). These results demonstrate that the pronounced intimal hyperplasia in cuff-injured $\mathrm{HCII}^{+-}$mice is due to enhanced proliferation of vascular mesenchymal cells.

Enhanced vascular expression of PAR-1 in cuff-injured $\mathrm{HCII}^{+/-}$mice. It has been well documented that enhanced PAR-1 expression results in development of restenosis after balloon angioplasty and atherosclerosis $(7,8,26-28)$. Therefore, we hypothesized that one of the
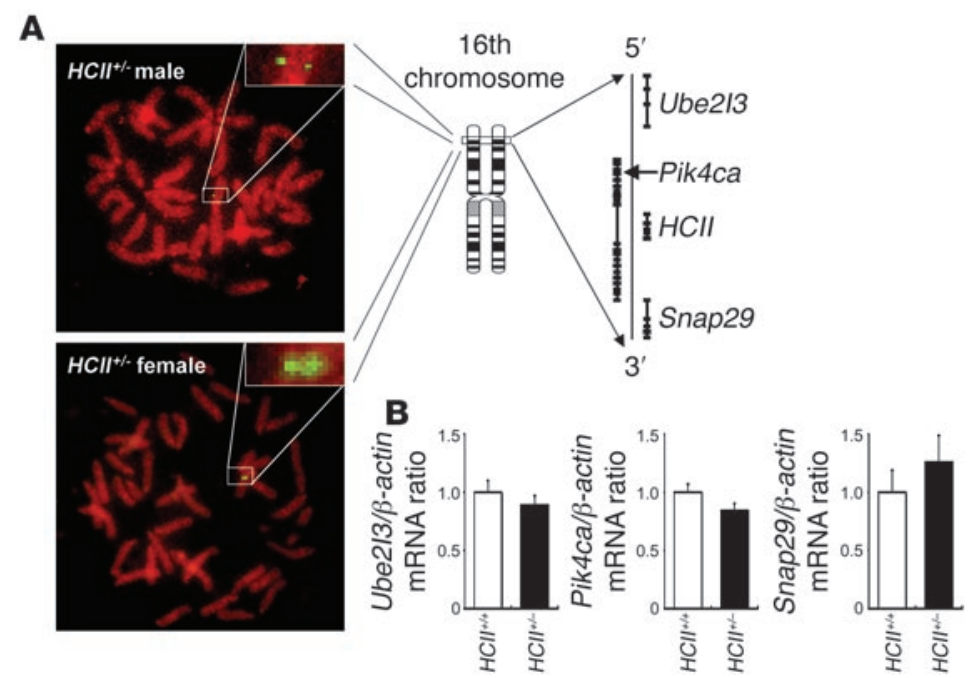

\section{Figure 2}

Noninterference of $\mathrm{HCll}$ targeting vector introduction into murine genome. (A) FISH analysis using a phosphoglycerate kinase-neomycin cassette probe and genomic map around the $\mathrm{HCll}$ genome. Single green spots in male and female $\mathrm{HCll}+-$ murine chromosomes indicate no random integration and adequate homologous recombination of the $\mathrm{HCll}$ targeting vector. Original magnification, $\times 1,000 ; \times 4,000$ (insets). (B) Real-time PCR analysis for mRNA quantification of genes located around the $\mathrm{HCll}$ genome in $\mathrm{HCll}^{+/+}$(white bars) and $\mathrm{HCll}^{+/-}$mice (black bars). Values were normalized by arbitrarily setting the measurement for $\mathrm{HCll}^{+/+}$mice to 1.0. Ube2/3, ubiquitin-conjugating enzyme E2L3; Pik4ca, phosphatidylinositol 4-kinase, catalytic, alpha polypeptide; Snap29, synaptosomal-associated protein. 
A
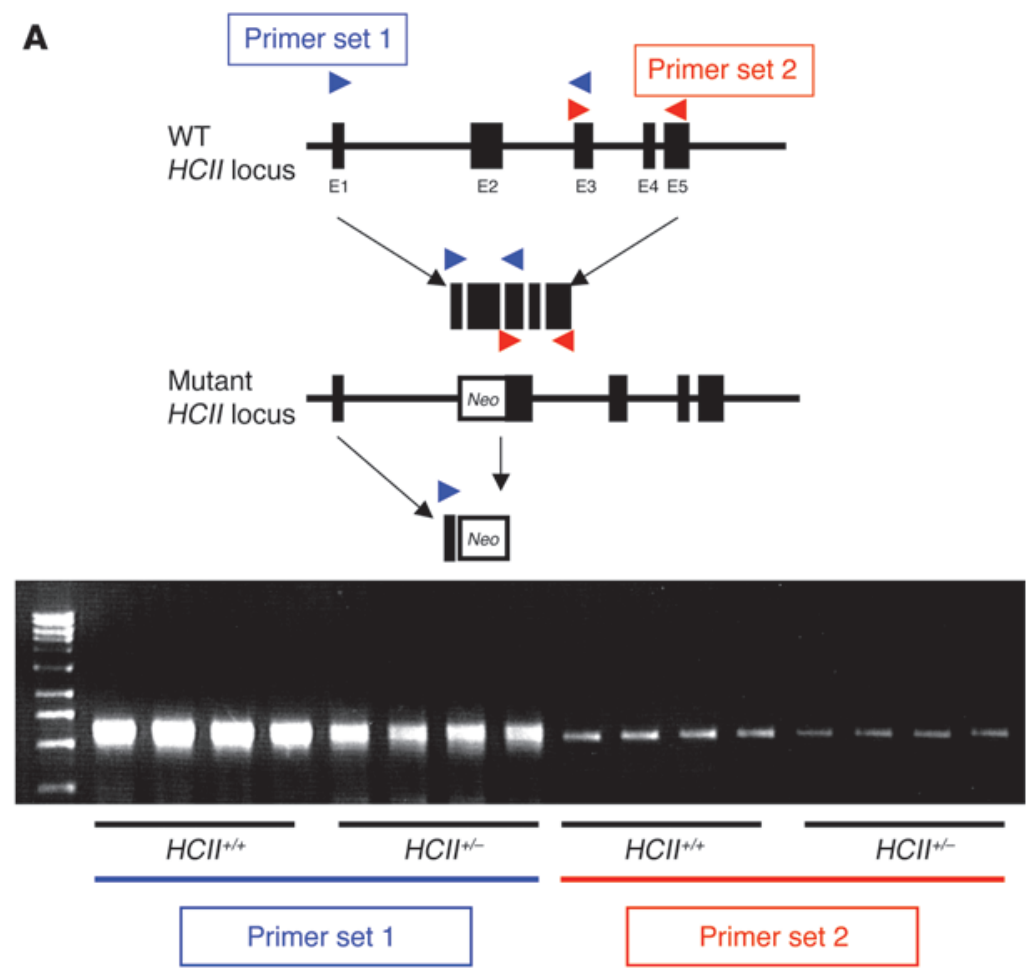

B

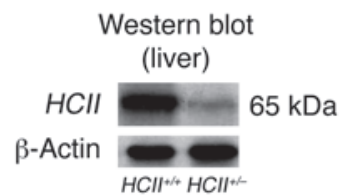

C

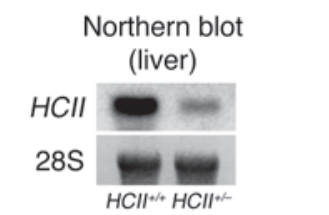

D

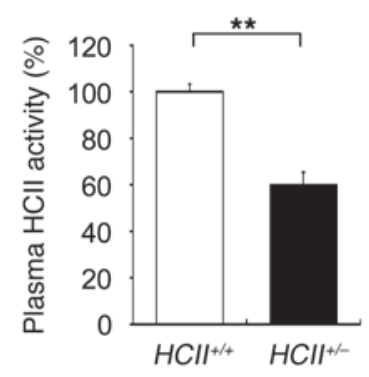

Figure 3

Analysis of $\mathrm{HCll}$ gene transcripts, protein, and plasma activity. (A) Conventional RT-PCR analysis of full-length $H C / l$ gene. (B) Western blot analysis of hepatic $\mathrm{HCll}$ protein in $\mathrm{HCl}^{+/+}$and $\mathrm{HCl}^{-/-}$mice. (C) Northern blot analysis of hepatic $\mathrm{HCll}$ mRNA in $\mathrm{HCll}^{+/+}$and $\mathrm{HCll}+/-$ mice. (D) Plasma $\mathrm{HCll}$ activity in $\mathrm{HCll}^{+++}$(white bar) and $\mathrm{HCll+/}$ mice (black bar). Values are expressed as mean $\pm \mathrm{SEM}$. ${ }^{\star \star} P<0.01 . n=12$ in each group for plasma HCll activity.

causes of accelerated intimal hyperplasia in cuff-injured $\mathrm{HCII}^{+/-}$ mice is enhancement of thrombin receptor expression in the vascular wall. To test this hypothesis, we examined vascular expression of PAR-1 in the vascular walls of these mice. In uninjured vessels, PAR-1 expression was restricted to the thin endothelial layer in both $\mathrm{HCII}^{+/+}$and $\mathrm{HCII}^{+/-}$mice (Figure 7A). After cuff injury, PAR-1expressing cells were distributed more widely, with a marked increase in the thickness of the intimal layer in $\mathrm{HCII}^{+/-}$mice compared with $\mathrm{HCII}^{+/+}$mice (Figure 7A).

Enhanced expression of inflammatory cytokines, chemokines, and transcription factors involved in VSMC proliferation in cuff-injured $\mathrm{HCII}^{+/-}$ mice. Intimal and adventitial hyperplasia caused by 4 weeks of polyethylene tube cuff placement around femoral arteries has been shown to be due to enhanced inflammatory reactions in response to vascular injury. To quantify gene expression levels of vascular remodeling factors, including inflammatory cytokines, chemokines, and transcription factors, that enhance VSMC proliferation, we performed real-time PCR analysis using removed arteries containing surrounding tissues of these mice. Without cuff injury, there was no significant difference between gene expression levels of $I l 1 b, I l 6$, monocyte chemoattractant protein-1 (Mcp1), early growth response protein-1 (Egr1) and Krüppel-like zinc finger transcription factor 5 (Klf5) in $\mathrm{HCII}^{+/+}$and $\mathrm{HCII}^{+/-}$mice (Figure $7 \mathrm{~B}$ ). Cuff injury caused notable enhancement of the expression of all of these genes in the vascular wall of $\mathrm{HCII}^{+/-}$mice, whereas only slight increases in the expression levels of these genes were observed in $\mathrm{HCII}^{+/+}$mice (Figure 7B). These results are consistent with the assumption that endogenous HCII attenuates inflammatory responses as well as transformation and migration of VSMCs in femoral arteries after cuff injury.

\section{Table 2}

Genotypes, plasma $\mathrm{HCl}$ antigen levels, and activity levels of second-generation mice derived from the mating of $\mathrm{HCl}+{ }^{+-} \mathrm{St}$. Louis and $\mathrm{HCl}+{ }^{+-}$ Tokushima mice

$\begin{array}{lcccc} & +/+ & +/- \text { (St. Louis) } & +/- \text { (Tokushima) } & -/- \text { (both mutants) } \\ \text { No. of pups } & 24 & 21 & 22 & 26 \\ \text { Plasma HCll antigen levels (\%) } & 102.0 \pm 2.6 & \text { ND } & 43.4 \pm 2.5 & 0.0 \pm 0.1 \\ \text { Plasma HCll activity levels (\%)A } & 101.3 \pm 3.1 & \text { ND } & 59.4 \pm 3.9 & 14.1 \pm 2.0\end{array}$


A
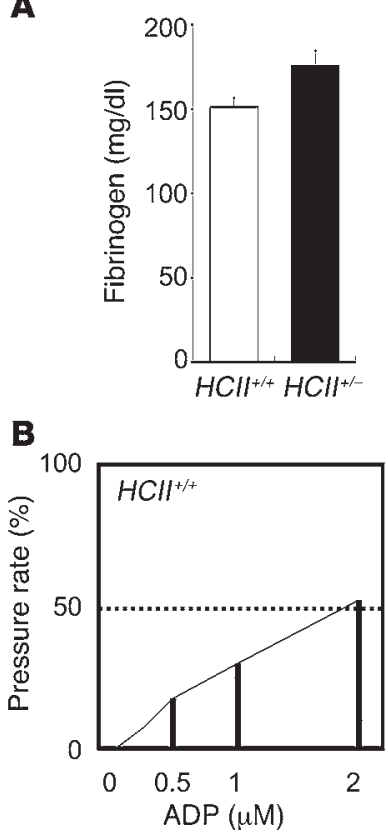
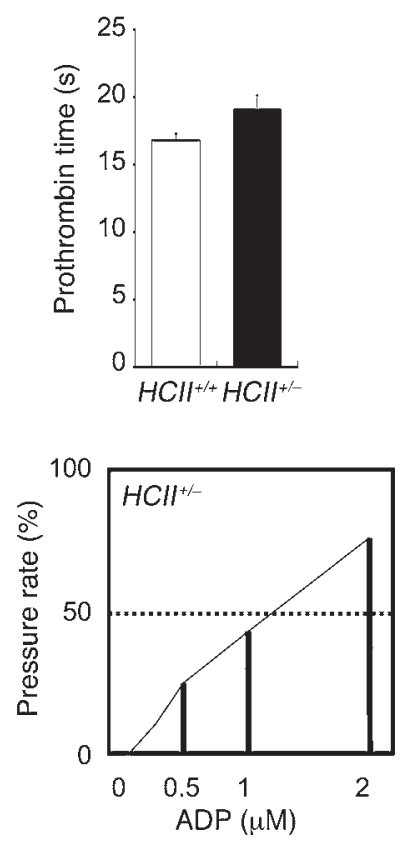
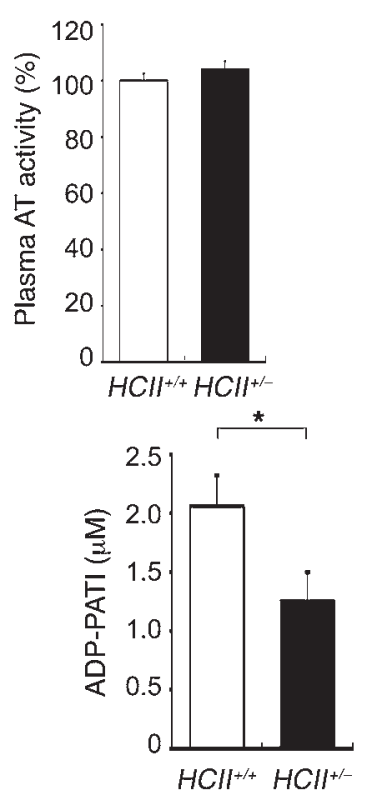

Figure 4

Effect of HCll deficiency on hemostatic examinations. (A) Plasma fibrinogen concentration, prothrombin time, and AT activity in $\mathrm{HCll}^{+/+}$(white bars) and $\mathrm{HCll}+$ - mice (black bars). Values are expressed as mean \pm SEM. $n=6-12$ in each group. (B) The left and middle panels show representative results of platelet aggregation analyzed by the screen filtration pressure method in $\mathrm{HCll}^{+++}$and $\mathrm{HCll}+/-$ mice. The platelet aggregation pressure of each reaction tube was determined as the pressure rate (percentage). For screen filtration pressure aggregometer study, the pressure rate was standardized using a grading curve produced by plotting 3 concentrations of ADP on the $x$ axis and pressure rate (percentage) on the $y$ axis. The concentration of ADP causing a $50 \%$ increase in pressure rate was calculated and applied as the platelet aggregatory threshold index (PATI) in $\mathrm{HCll}^{+++}$(white bar) and $\mathrm{HCll}^{+/-}$mice (black bar). $n=6$ in each group. Values are expressed as mean \pm SEM. ${ }^{*} P<0.05$.
Human purified HCII protein ameliorates aberrant vascular remodeling in cuff-injured $\mathrm{HCII}^{+/-}$mice. In order to determine whether supplementation with a large amount of HCII in vivo can prevent accelerated vascular remodeling in cuff-injured $\mathrm{HCII}^{+/-}$mice, we administered human purified HCII protein for 4 weeks after surgery in $\mathrm{HCII}^{+/-}$ mice. Since intraperitoneal injection of $45 \mathrm{mg} / \mathrm{kg}$ human purified $\mathrm{HCII}$ protein was able to maintain plasma HCII activity of greater than $100 \%$ for 48 hours in $\mathrm{HCII}^{+/-}$mice (Figure $8 \mathrm{~A}$ ), we administered this dose of HCII protein 3 times a week for 4 weeks. HCII protein administration markedly attenuated intimal hyperplasia and adventitial hyperplasia in cuff-injured $\mathrm{HCII}^{+/-}$mice to levels similar to those observed in cuff-injured WT mice treated with vehicle (Figure 8, $\mathrm{B}$ and $\mathrm{C}$ ). Thus, supplementation with HCII can ameliorate injuryinduced vascular remodeling in HCII-deficient mice in vivo.

Enhanced neointimal hyperplasia, increased incidence of arterial thrombosis, and normalization of aberrant vascular remodeling by buman purified HCII protein supplementation in wire-injured $\mathrm{HCII}^{+/-}$mice. In addition to the cuff injury model, we estimated vascular remodeling in
A

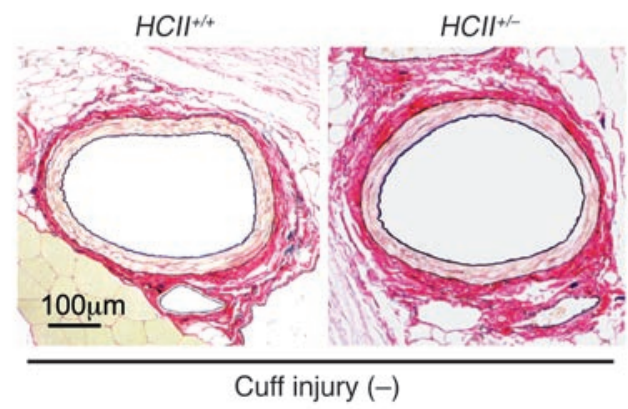

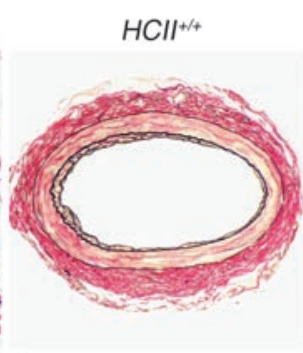

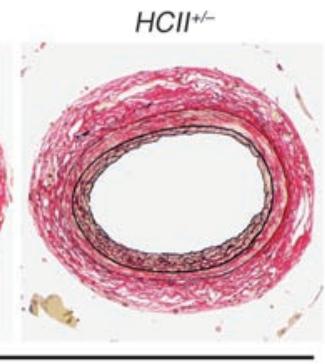

Cuff injury (+)
B

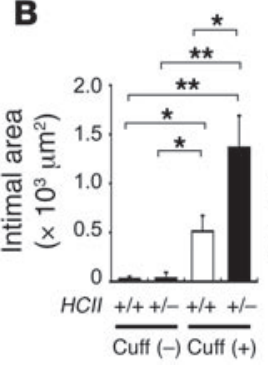

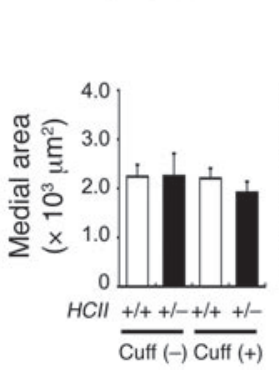
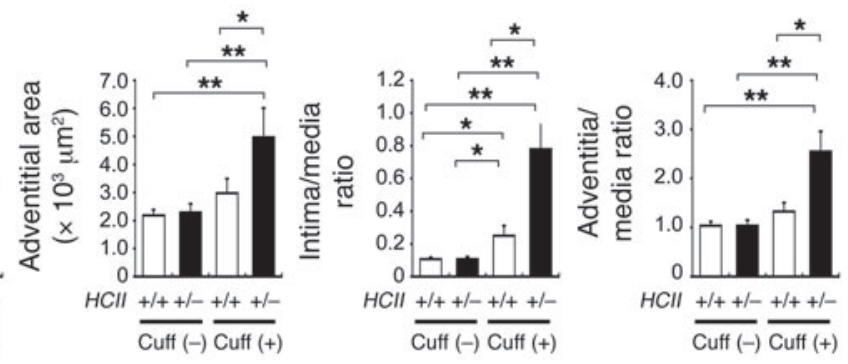

Figure 5

Histopathology of femoral arteries with and without cuff injury in $\mathrm{HCll}^{+/+}$and $\mathrm{HCl}+{ }^{+-}$mice. (A) Histological features of uninjured and cuff-injured femoral arteries. Cross sections of uninjured and cuff-injured arteries were obtained on day 28 of cuff injury and stained with Elastica-van Gieson. (B) Quantitative analysis of arterial intimal area, medial area, adventitial area, intima/media ratio, and adventitia/media ratio with and without cuff injury in $\mathrm{HCll}^{+++}$(white bars) and $\mathrm{HCll+/-}$ mice (black bars). Values are expressed as mean $\pm \mathrm{SEM}$. ${ }^{*} P<0.05$; ${ }^{*} P<0.01$. $n=12$ in each group. 
A

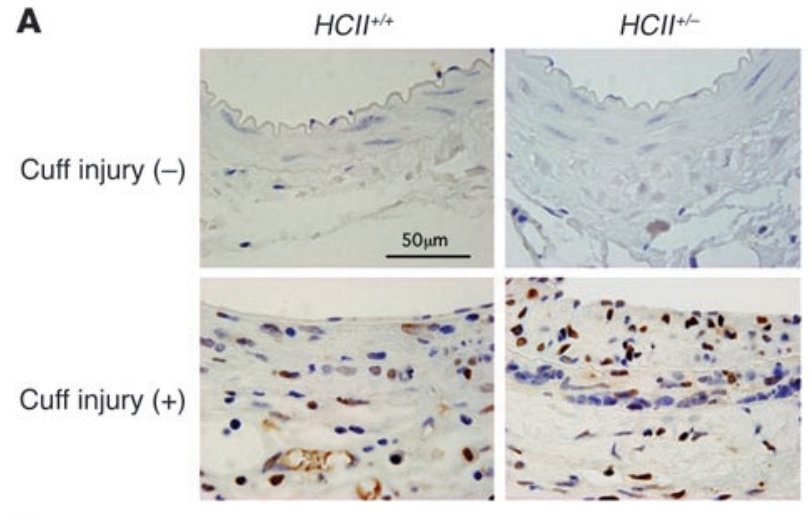

C

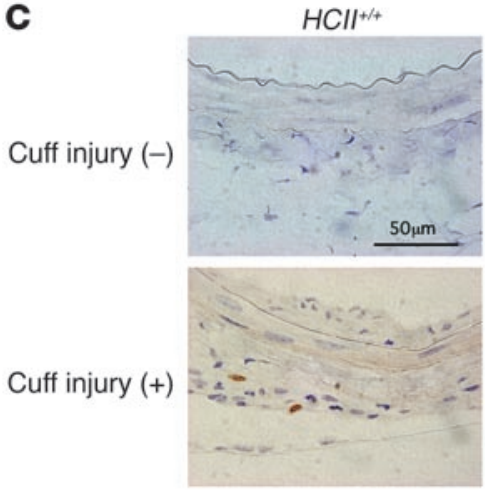

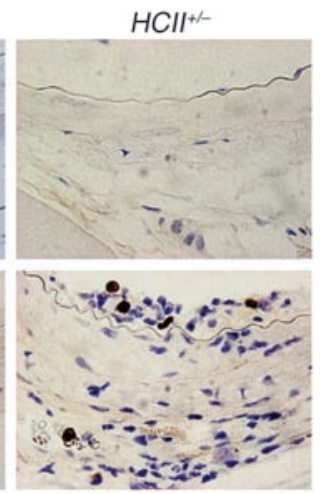

B

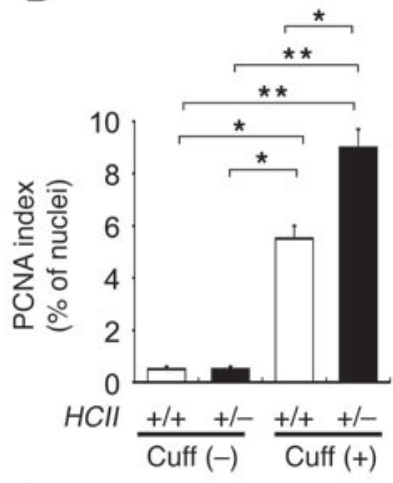

D

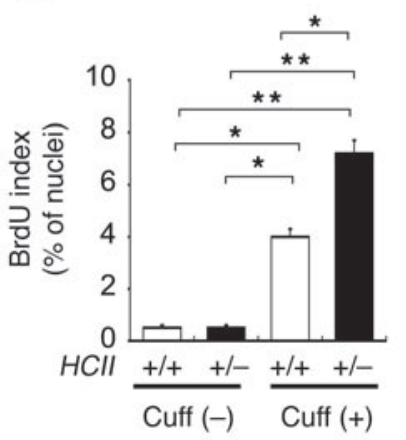

\section{Figure 6}

Immunostaining of proliferative vascular mesenchymal cells with PCNA and BrdU at the vascular wall with and without cuff injury in $\mathrm{HCll}^{+++}$and $\mathrm{HCll}^{+/}$ mice. (A) PCNA staining of the vascular wall with and without cuff injury in $\mathrm{HCll}^{++}$and $\mathrm{HCll}^{+/-}$mice. (B) Quantitative analysis of PCNA-positive cells in intima and media with and without cuff injury in $\mathrm{HCll}^{+/+}$(white bars) and $\mathrm{HCll}+$ - mice (black bars). Values are expressed as mean \pm SEM. ${ }^{*} P<0.05$; ${ }^{\star *} P<0.01 . n=8$ in each group. (C) BrdU staining of the vascular wall with and without cuff injury in $\mathrm{HCll}^{+/+}$and $\mathrm{HCl}+{ }^{+-}$mice. (D) Quantitative analysis of BrdU-positive cells in intima and media with and without cuff injury in $\mathrm{HCll}^{+/+}$(white bars) and $\mathrm{HCll}^{+/-}$mice (black bars) Values are expressed as mean \pm SEM. ${ }^{*} P<0.05 ;{ }^{* *} P<0.01$. $n=8$ in each group.
$\mathrm{HCII}^{+/+}$and $\mathrm{HCII}^{+/-}$mice using a wire insertion injury model (29). Wire-injured femoral arteries in $\mathrm{HCII}^{+/-}$mice revealed prominent neointimal hyperplasia and a high intima/media ratio compared with those in $\mathrm{HCII}^{+/+}$mice (Figure 9, A and B). Moreover, wire injury caused a higher incidence (20\%) of arterial occlusion due to thrombosis in $\mathrm{HCII}^{+/-}$mice than in $\mathrm{HCII}^{+/+}$mice (10\%) (Figure 9A). Those abnormalities were ameliorated by human purified HCII protein supplementation, as was found in the cuff injury model in $\mathrm{HCII}^{+/-}$mice (Figure 9, A and B).

HCII deficiency causes accelerated atherosclerotic plaque formation and PAR-1 expression in the aortic root of apoE $E^{-/-}$mice. In order to examine the role of $H C I I$ action against lipid-induced atherosclerosis, we generated $\mathrm{HCII}^{+/-}$apoE $E^{-/-}$mice and compared the doublemutant mice with $\mathrm{HCII}^{+/+} a p o E^{-/-}$mice. There were no significant differences in fasting plasma levels of total cholesterol, triglyceride, high-density lipoprotein cholesterol, free fatty acid, and glucose $\left(\mathrm{HCII}^{+/+}\right.$apoE $\mathrm{E}^{-/-}$versus $\mathrm{HCII}^{+/-}$apoE $E^{-/-}$mice: $300 \pm 15.4$ versus $280.1 \pm 17.2 \mathrm{mg} / \mathrm{dl} ; 41.3 \pm 2.6$ versus $44.5 \pm 4.9 \mathrm{mg} / \mathrm{dl} ; 10.3 \pm 0.8$ versus $11.1 \pm 1.3 \mathrm{mg} / \mathrm{dl} ; 554.2 \pm 58.4$ versus $506.4 \pm 54.5 \mathrm{mEq} / \mathrm{l}$; and $81.1 \pm 5.0$ versus $81.7 \pm 6.4 \mathrm{mg} / \mathrm{dl}$; respectively; $n=14$ in each group). Atherosclerotic plaque area was significantly increased in the aortic root of $\mathrm{HCII}^{+/-}$apoE $\mathrm{E}^{-/-}$mice compared with that in $\mathrm{HCII}^{+/+}$apoE $E^{-/-}$ mice (Figure 10A). In addition, lipid deposition and PAR-1-positive cells in the plaques were more prominently observed in the aortic root of $\mathrm{HCII}^{+/-}$apoE $\mathrm{E}^{-/-}$mice than $\mathrm{HCII}^{+/+} a p o E^{-/-}$mice (Figure 10B).

HCII deficiency increases oxidative stress in apoE $E^{-/-}$mice. Because it has been recognized that increased oxidative stress promotes cardiovascular diseases such as atherosclerosis and hypertension (30), we investigated superoxide production in $\mathrm{HCII}^{+/+} \mathrm{apoE}^{-/-}$and $\mathrm{HCII}^{+/-}$apoE $\mathrm{E}^{-/-}$mice. The number of dihydroethidium-stained (DHE-stained) spots in the aortic root was greater in $\mathrm{HCII}^{+/-}$ apo $E^{-/-}$mice than in $\mathrm{HCII}^{+/+}$apo $E^{-/-}$mice (Figure 11A). Moreover, daily urinary excretion levels of 8-hydroxy-2'-deoxyguanosine (8OHdG), as a marker of oxidative stress-induced DNA damage, were higher in $\mathrm{HCII}^{+/-}$apoE $E^{-/-}$mice than in $\mathrm{HCII}^{+/+}$apoE $\mathrm{E}^{-/-}$mice (Figure 11B). These results suggest that HCII attenuates oxidative stress and cellular damage. The mechanisms by which HCII exerts such an effect remain to be clarified.

\section{Discussion}

In the present study, HCII-deficient mice were created by targeted disruption of the HCII gene and were used to examine the role as well as the mechanism of protective action of HCII against thrombin-induced vascular remodeling. Unexpectedly, mice with homozygous deletion of HCII exhibited embryonic lethality after careful backcrossing for 10 generations with C57BL/6J strain (Table 1 and Figure $1 \mathrm{C}$ ). $\mathrm{HCII}^{-/-}$mice generated previously by $\mathrm{He}$ et al. survived throughout the fetal period and after birth with normal growth and life span (25). He et al. deleted exon 1 in their targeting vector, which is the same as exon 2 in our description of the HCII gene. Based on the results of a study by Kamp and Ragg showing that the genomic structure of murine and human HCII consists of 5 exons that are interrupted by 4 introns (31), we called exon 1 in their report exon 2 in this paper (Figure 1A). He et al. inserted a phosphoglycerate kinase-neomycin cassette to replace exon 2 (exon 1 in their description), whereas we inserted a neomycin cassette with polyA termination to silence transcription. In addition, they screened a bacterial artificial chromosome (BAC) library made from 129/SvJ mouse genomic DNA to construct the HCII targeting vector, and the targeting vector was introduced into $129 / \mathrm{SvJ}$ ES cells. Then their HCII heterozygous mutant mice ( $\mathrm{HCII}^{+/-}$St. Louis) were backcrossed with WT C57BL/6 mice to produce a nearly congenic 
A

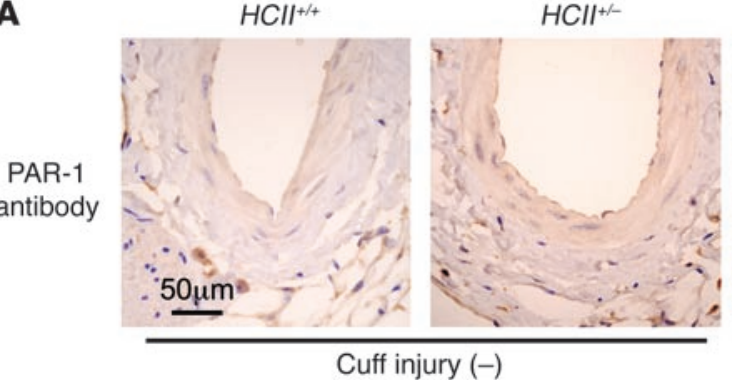

B

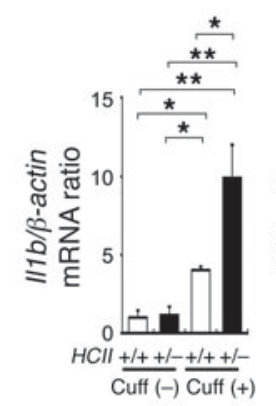

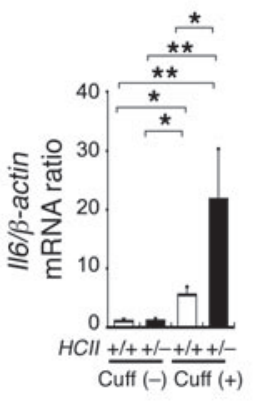

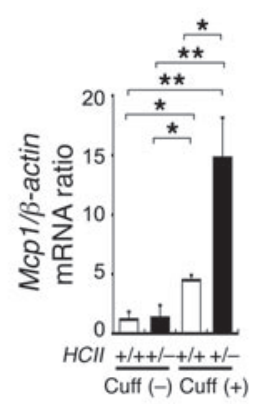

$\mathrm{HCll}+/+$

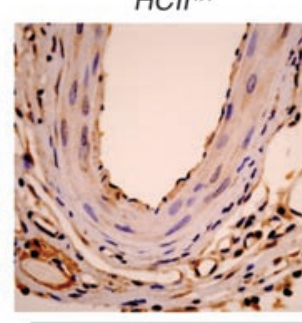

Cuff injury $(+$
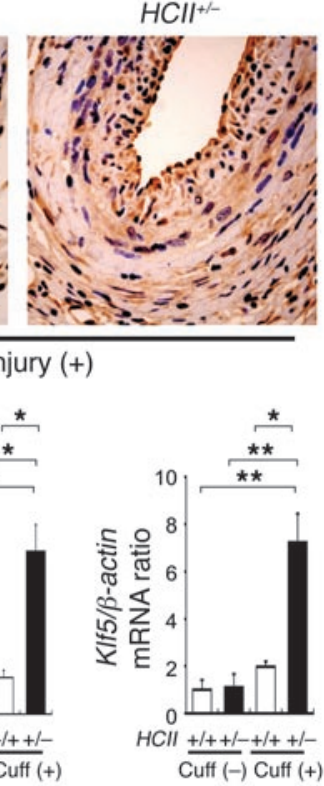

Figure 7

Expression of PAR-1, inflammatory cytokines and chemokines, and vascular remodeling-related transcription factors with and without cuff injury in $\mathrm{HCll}^{+/+}$and $\mathrm{HCll}+/-$ mice. (A) Immunohistochemical staining of PAR-1 with and without cuff injury in $\mathrm{HCll}^{++}$and $\mathrm{HCll}^{+/-}$mice. (B) Gene expression of vascular remodeling factors at the vascular wall with and without cuff injury in $\mathrm{HCll}^{+/+}$(white bars) and $\mathrm{HCll}^{+/-}$mice (black bars). Real-time PCR analyses of $/ 11 \mathrm{~b}$, II6, Mcp1, Egr1, and Klf5 were performed in $\mathrm{HCll}^{+++}$and $\mathrm{HCll}^{+/-}$mice. Values were normalized by arbitrarily setting the measurement in $\mathrm{HCl}^{+/+}$mice without cuff injury to 1.0. Values are expressed as mean \pm SEM. ${ }^{\star} P<0.05 ;{ }^{*} P<0.01 . n=10$ in each group.

strain of mice containing the HCII-null allele (25). On the other hand, we screened a phage library made from C57BL/6 mouse genomic DNA, and we introduced the targeting vector into TT2 (hybrid with C57BL/6J and CBA) ES cells. Our HCII heterozygous mutant mice $\left(\mathrm{HCII}^{+/}\right.$- Tokushima) were mated with WT C57BL/6J mice and backcrossed for 10 generations. From these results, we have reached the conclusion that complete $\mathrm{KO}$ of HCII gene results in embryonic lethality. We do not have plausible explanation for the discrepancy in fetal development between the studies by He et al. and ours. We speculate that a minor strain-dependent difference in genetic background may have caused the loss of embryonic lethality of $\mathrm{HCII}^{-/}$St. Louis mice.

Although a family with congenital homozygous HCII deficiency was reported (32) with a Glu428Lys missense mutation in both alleles (33), the homozygous HCII-deficient patients showed $5 \%-13 \%$ of normal HCII activity, and there has been no report of humans with complete HCII deficiency. Delorme et al. reported that thrombin generation is increased during normal pregnancy and that a greater proportion of thrombin molecules form a complex with HCII in plasma in pregnant woman than in nonpregnant women (34). It has also been reported that HCII levels are significantly decreased in women with severe preeclampsia (35). Giri and Tollefsen have suggested that DS activates HCII in the fetal blood vessels or in the stroma of placental villi after injury to the syncytiotrophoblast layer and thereby inhibit fibrin generation in the placenta (36). Thus, a certain level of HCII activity may be required for the survival of human fetuses. In the present study, $\mathrm{HCII}$ homozygous mutant mice generated by mating $\mathrm{HCII}^{+/-}$ Tokushima mice with $\mathrm{HCII}^{+}-$St. Louis mice survived. Although young. Although larger clinical studies are needed, heterozygous HCII-deficient subjects appear to suffer from advanced atherosclerotic lesions after the development of vascular injuries with aging (37). Indeed, a female member of a family with type I congenital HCII deficiency with about half of the normal plasma HCII activity level was found to have multiple atherosclerotic lesions, including lesions in coronary, carotid, renal, and abdominal aortic arteries, when she was 66 years old (22). Her elder brother, who had the same heterozygous mutation and reduced level of plasma HCII activity, also had multiple cerebral infarctions when he was 63 years of age. In addition, our 2 clinical studies on the protective role of HCII against the development of atherosclerosis demonstrated a protective role of HCII against progression of carotid atherosclerosis and in-stent restenosis after percutaneous coronary intervention $(23,24,38)$. Schillinger et al. also demonstrated that a high level of plasma HCII activity is associated with reduced incidence of restenosis after femoropopliteal stenting (39). In the present study, $\mathrm{HCII}^{+/}$mice exhibited no obvious differences in vascular structure compared with $\mathrm{HCII}^{+/+}$mice under the condition of no vascular stress. However, arterial cuff injury and wire injury caused prominent hyperplasia of the intimal area in $\mathrm{HCII}^{+/}$mice compared with $\mathrm{HCII}^{+/+}$mice (Figures 5 and 9). Since HCII exerts its antithrombin action via a complex formation with DS and since DS is produced by VSMCs or fibroblasts and is deposited within the matrix of the vascular wall, the antithrombin action of HCII is exerted mostly at the injured vascular wall, where HCII is activated by its binding to DS. In the present study, cuff injury of the femoral artery of $\mathrm{HCII}^{+-}$mice resulted in broad expression of PAR-1 in the vascular wall (Figure 7A). The enhanced expression of 
A

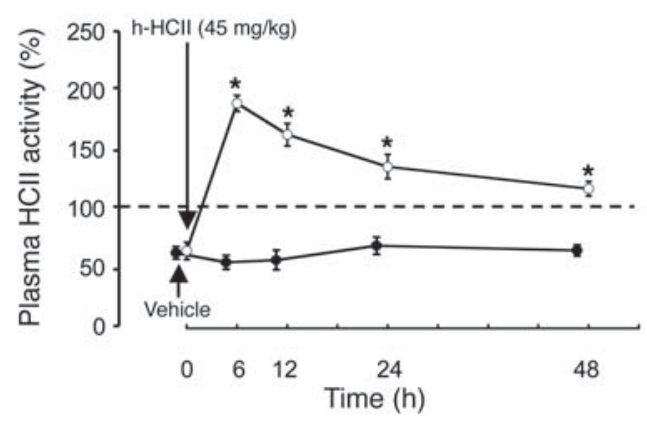

B

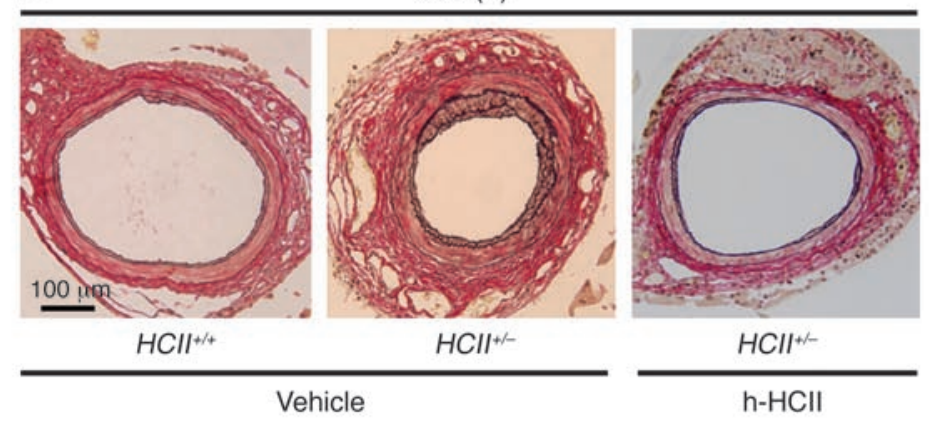

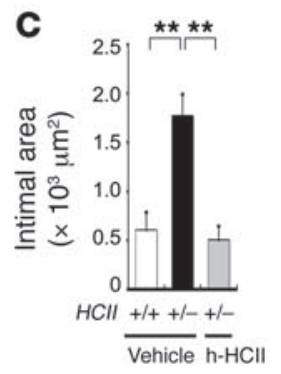
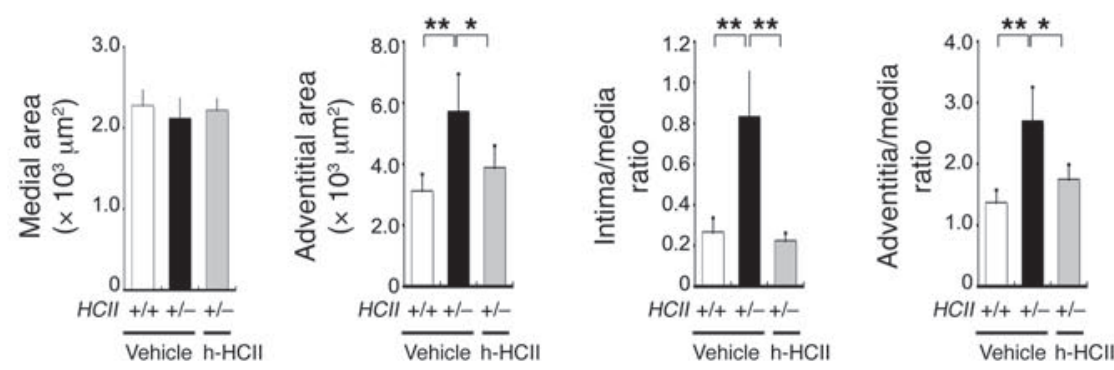

\section{Figure 8}

Effects of human purified $\mathrm{HCll}$ supplementation on cuff-injured vascular remodeling in $\mathrm{HCll+-}$ mice. (A) Time course of plasma $\mathrm{HCll}$ activity in $\mathrm{HCll}+$ - mice after an intraperitoneal injection of human purified $\mathrm{HCll}$ protein (h-HCll) (open circles) or a vehicle alone (filled circles). ${ }^{*} P<0.05$. $n=4$ in each group. (B) Representative histological findings of cuff-injured femoral arteries. Micrographs of cross sections of cuff-injured arteries stained with Elastica-van Gieson on day 28 in $\mathrm{HCll}^{+/+}$mice treated with vehicle and in $\mathrm{HCll}^{+/-}$mice treated with vehicle alone or human purified HCII protein are shown. (C) Quantitative comparison of arterial intimal area, medial area, adventitial area, intima/media ratio, and adventitia/ media ratio in cuff-injured $\mathrm{HCll}^{+/+}$mice treated with vehicle (white bars) and $\mathrm{HCl}+{ }^{+-}$mice treated with vehicle (black bars) or human purified $\mathrm{HCll}$ protein (gray bars). Values are expressed as mean \pm SEM. ${ }^{*} P<0.05 ;{ }^{* *} P<0.01 . n=10$ in each group.

PAR-1 in turn is expected to further promote vascular remodeling in $\mathrm{HCII}^{+/-}$mice. Taken together, these results are consistent with the assumption that the vascular protective role of HCII is exerted most efficiently at sites with vascular injury where thrombin is activated to stimulate vascular remodeling.

Thrombin stimulates migration and proliferation of mesenchymal cells, including VSMCs, via binding to its cell-surface receptors, PARs (40-42). Receptor-mediated actions of thrombin enhance the expression of inflammatory cytokines and chemokines and are associated with pathological conditions such as atherosclerosis and restenosis after vascular interventions $(43,44)$. Activation of PAR-1 by thrombin also enhances NF-KB activation in endothelial cells (45) and VSMCs (46). Because upregulation of these cytokines and chemokines that contribute to the promotion of vascular remodeling (47-50) is known to enhance NF- $\mathrm{KB}$ activation, there is a possibility that the action of thrombin on migration and proliferation of cells in the vascular wall is mediated by its stimulatory effect on the expression of inflammatory cytokines and chemokines. This possibility is supported by an observation by Isoda et al. that deficiency of an IL-1 receptor antagonist promotes neointimal formation in mice after cuff injury (51). The present study demonstrated that gene expression of inflammatory cytokines (Il1b and Il6), a chemokine (Mcp1), and transcriptional factors involved in VSMC proliferation (Egr1 and Klf5) was markedly upregulated in cuff-injured $\mathrm{HCII}^{+/-}$mice (Figure 7B). Based on these observations, we suggest that HCII inhibits vascular remodeling via its inhibitory effect on the expression of these cytokines and chemokines by blocking receptor-mediated thrombin action.
In addition, wire injury caused not only prominent neointimal hyperplasia but also a high incidence of arterial occlusion due to thrombosis. This result is consistent with the previous finding that HCII-deficient mice manifested acceleration of arterial thrombosis formation after photochemical endothelium injury (25). In the present study, we found that HCII deficiency enhanced platelet aggregation. Since PARs exists in platelets, HCII may have a suppressive effect on platelet aggregation.

Since it is well known that dyslipidemia promotes arterial plaque formation leading to cardiovascular events, we investigated the role of HCII action against high cholesterol-induced atherosclerosis using $\mathrm{HCII}^{+/-}$apo $\mathrm{E}^{-/-}$mice. As expected, the double mutant mice manifested exaggeration of atherosclerotic lesion formation with increased lipid deposition and enhanced PAR-1 expression. Interestingly, the double mutant mice showed higher levels of oxidative stress than apoE single mutant mice. These results suggest that HCII has antioxidant potency at the injured vascular wall. Based upon these observations, inactivation of PARmediated thrombin actions and attenuation of oxidative stress at sites of injury of the arterial wall is an attractive approach for protection against atherosclerosis and restenosis after percutaneous coronary intervention.

Our observations were further corroborated by a study using $\mathrm{HCII}^{-/-}$St. Louis mice on an apoE $E^{+/+}$or $a p o E^{-/-}$background (Douglas M. Tollefsen, unpublished observations). In that study, $\mathrm{HCII}^{-1-}$ St. Louis mice exhibited greater neointimal hyperplasia of carotid arteries after wire injury than $\mathrm{HCII}^{+/+}$mice. In addition, it was revealed that $\mathrm{HCII}^{-/-}$apo $E^{-/-}$mice developed larger aortic 
A

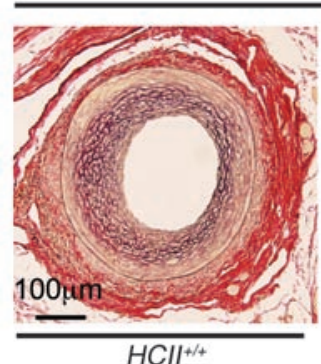

$\mathrm{HCll}+/+$

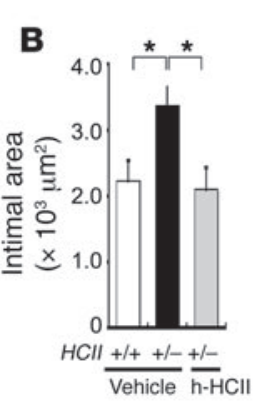

Wire injury

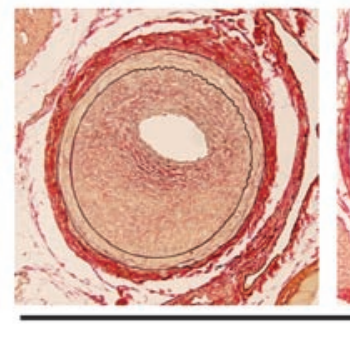

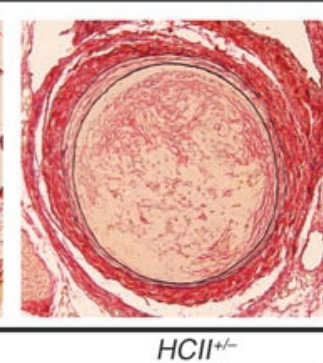

$\mathrm{HCl}+{ }^{+/}$

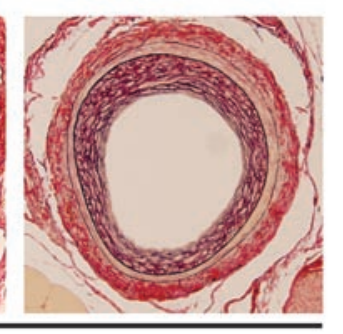

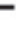
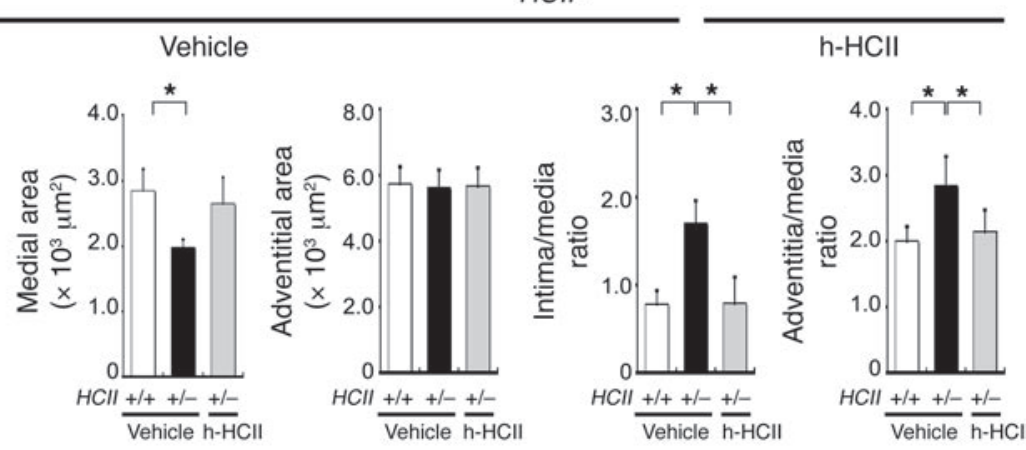

Figure 9

Effects of $\mathrm{HCll}$ deficiency and of human purified $\mathrm{HCll}$ supplementation on wire-injured vascular remodeling (A) Representative histological findings for wire-injured femoral arteries. Micrographs of cross sections of wireinjured arteries stained with Elastica-van Gieson on day 28 in $\mathrm{HCll}^{+++}$mice treated with vehicle and in $\mathrm{HCll}^{+/-}$ mice treated with vehicle alone or human purified HCIl protein are shown. (B) Quantitative comparison of arterial intimal area, medial area, adventitial area, intima/media ratio, and adventitia/media ratio in wire-injured $\mathrm{HCl/++}$ mice treated with vehicle (white bars) and $\mathrm{HCll}+-$ mice treated with vehicle (black bars) or human purified $\mathrm{HCll}$ protein (gray bars). Values are expressed as mean \pm SEM. ${ }^{*} P<0.05 . n=8-10$ in each group.

plaque formation than $\mathrm{HCII}^{+/}$apoE $\mathrm{E}^{-/-}$mice. Taken together, the results of the present study and those of the study by Tollefsen and colleagues demonstrate that HCII protects against thrombin-induced remodeling of an injured vascular wall by inhibiting thrombin action. Since HCII is activated mainly at the vascular wall by complex formation with DS, HCII or agents that mimic these characteristics of HCII can act mostly at the vascular wall. Such agents can protect against vascular remodeling without causing coagulatory disturbance or bleeding tendency in patients with atherosclerosis or cardiovascular disease.

\section{Methods}

Gene targeting and genotyping for HCII mutant mice. A mouse genomic C57BL/6 library (female, 6-8 weeks old, vector: Lambda DASH II, insert size: 9-23 kb; Stratagene) was screened with a human HCII cDNA probe. A $17-\mathrm{kb}$ fragment of the mouse $\mathrm{HCII}$ genome containing coding exons 2-5 was used to construct a targeting vector. A 120 -bp fragment containing the ATG sequence of exon 2 was deleted, and a phosphoglycerate kinase-neomycin cassette including polyA termination was inserted. Diphtheria toxin fragment A gene (DTA) was bound to the $5^{\prime}$ end of the targeting vector for negative selection. TT2 (hybrid with C57BL/6J and CBA) ES cells were transfected with a linearized targeting vector $\left(25 \mathrm{mg}\right.$ per $1.0 \times 10^{7}$ cells) using a Bio-Rad Gene Pulser II at $250 \mathrm{~V}$ and $500 \mathrm{~F}$ and grown under G418 selection as described previously (52-55). Targeted ES cell clones were identified by Southern blot analysis with probe A as an external probe (WT allele denotes a $12-\mathrm{kbp}$ band; mutant allele denotes a $5-\mathrm{kbp}$ band) and probe $\mathrm{B}$ as an internal probe (mutant allele without random integration denotes a single 7-kbp band; Figure 1A) after HindIII digeswere intercrossed to obtain homozygous mutant mice. In addition, we obtained reproductive $H C I I$ heterozygote mutant mice established by Tollefsen's laboratory (25). Genotyping for detection of their HCII mutant allele was performed as described previously (25). Reproductive C57BL/6 background $\mathrm{apoE}^{-/-}$mice were purchased from Taconic. $\mathrm{HCII}^{+/+} a \mathrm{poE}^{-/-}$ mice and $\mathrm{HCII}^{+/-} \mathrm{apoE}^{-/-}$mice were generated by crossbreedings of male and female $\mathrm{HCII}^{+/-} a \mathrm{poE}^{+/-}$mice. These animals were housed in a specific pathogen-free facility under climate-controlled conditions with a 12-hour light/12-hour dark cycle and were provided with standard diet chow (Oriental Yeast Co.) and water ad libitum. $\mathrm{HCII}^{+/+}$and $\mathrm{HCII}^{+/-}$mice were sacrificed and analyzed at the age of 20 weeks, whereas $\mathrm{HCII}^{+/} a \mathrm{poE}^{-/-}$ mice and $\mathrm{HCII}^{+/-} \mathrm{apoE}^{-/-}$mice were sacrificed and analyzed at the age of 30 weeks. All experimental procedures were approved of by the Animal Research Committee of the University of Tokushima Graduate School.

Chromosome preparation and staining of splenic lymphocytes in HCII mutant mice. Culture of murine lymphocytes was performed as described previously (56). Lymphocytes were isolated from spleens of adult $\mathrm{HCII}^{+/-}$male and female mice, washed twice with PBS solution, and transferred to 65-mm dishes containing $5 \mathrm{ml}$ RPMI 1640 supplemented with $20 \%$ fetal calf serum, $3 \mathrm{mg} / \mathrm{ml}$ concanavalin A (Type IV-S; Sigma-Aldrich), $10 \mathrm{mg} / \mathrm{ml}$ lipopolysaccharide (Sigma-Aldrich), and $5 \times 10^{-5} \mathrm{M}$ mercaptoethanol. Cultures with concentrations of $0.5 \times 10^{6}$ to $1.0 \times 10^{6} \mathrm{cells} / \mathrm{ml}$ were incubated at $37^{\circ} \mathrm{C}$ in a humidified mixture of $95 \%$ air and $5 \% \mathrm{CO}_{2}$. Either thymidine $(300 \mathrm{mg} / \mathrm{ml})$ or $2 \times 10^{-7} \mathrm{M}$ methotrexate and $200 \mathrm{mg} / \mathrm{ml} \mathrm{BrdU}$ (Sigma-Aldrich) were added to the cultures, and then the lymphocytes were washed and transferred to culture medium. Finally, the cells were fixed with 3:1 methanol/glacial acetic acid and were air dried. The chromosome slides were stained with $3 \%$ Giemsa solution ( $\mathrm{pH}$ 6.8) for analysis of G- and R-banding patterns. 
A
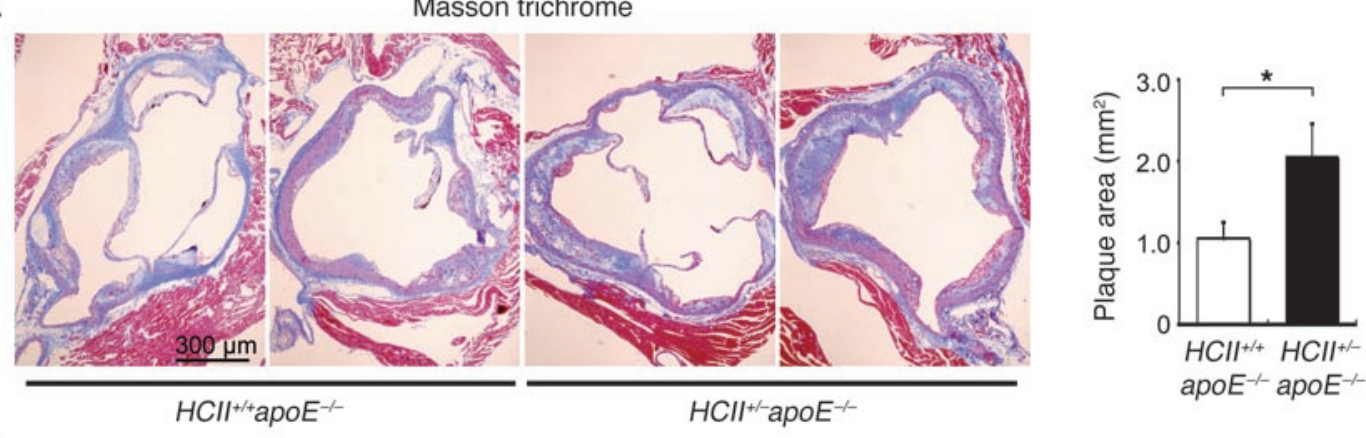

B

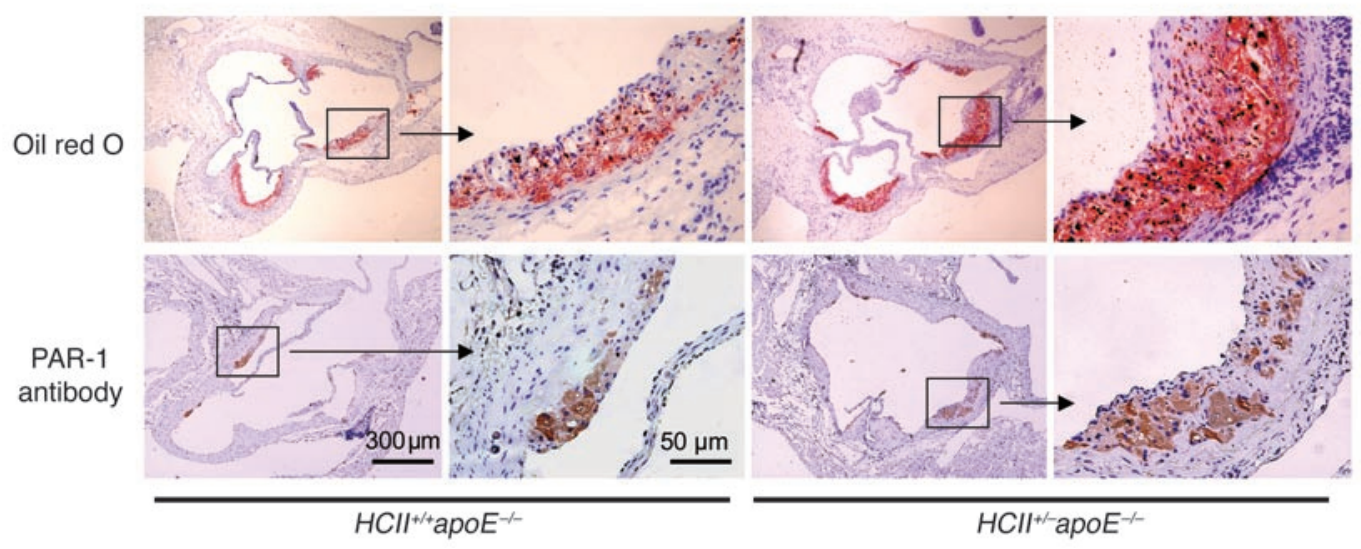

Figure 10

Quantification and characterization of atherosclerotic lesions in $\mathrm{HCll}^{+/+}$apo $E^{-/-}$and $\mathrm{HCll}{ }^{+-}$apo $\mathrm{E}^{-/-}$mice. (A) The left panel shows representative histological findings in Masson trichrome-stained serial sections of the aortic root in $\mathrm{HCll}^{+/+}$apoE $E^{-/-}$and $\mathrm{HCll}^{+/-}$apoE $E^{-/-}$mice. The right panel shows mean values of the atherosclerotic plaque area in $\mathrm{HCll}^{+/+}$apo $\mathrm{E}^{-/-}$(white bar) and $\mathrm{HCll}^{+/-}$apo $\mathrm{E}^{-/-}$mice (black bar). Values are expressed as mean \pm SEM. ${ }^{*} P<0.05 . n=12$ in each group. (B) Representative histological findings in oil red O- (upper panels) and PAR-1-stained (lower panels) serial sections of the aortic root in $\mathrm{HCll}^{+/+}$apo $E^{-/-}$and $\mathrm{HCll}{ }^{+-}$apo $E^{-/-}$mice.

FISH analysis using a phosphoglycerate kinase-neomycin cassette probe. Phosphoglycerate kinase-neomycin cassette cDNA of $1.6 \mathrm{kbp}$ was labeled by nick translation (Roche) with biotin 16-dUTP (Roche). The labeled probe was ethanol precipitated with $625 \mu \mathrm{g} / \mathrm{ml}$ sonicated salmon sperm DNA and transfer RNA and then denatured for 10 minutes at $75^{\circ} \mathrm{C}$ in $100 \%$ formamide and kept at $4^{\circ} \mathrm{C}$. The hybridization solution was mixed with an equal volume of denatured probe in formamide to make a final concentration of $50 \%$ formamide, $2 \times$ sodium chloride-sodium citrate, $10 \%$ dextran sulfate, and $2 \mathrm{mg} / \mathrm{ml} \mathrm{BSA}$. The biotin-labeled DNA was mixed at a final concentration of $5 \mu \mathrm{g} / \mathrm{ml}$ and used at $100 \mathrm{ng}$ per slide. The mixture was put on denatured chromosome slides, covered with paraffin, and incubated overnight at $37^{\circ} \mathrm{C}$. In situ hybridization of metaphase chromosomes was subsequently performed as described previously (56).

RNA isolation. Liver and femoral arteries were perfused and rinsed with physiological saline. Total RNA was isolated by acid guanidinium thiocyanate-phenol-chloroform extraction using TRIzol Reagent (Invitrogen). RNA concentrations were measured spectrophotometrically at $260 \mathrm{~nm}$, and samples were stored in diethylpyrcarbonate-treated water at $-80^{\circ} \mathrm{C}$.

Conventional RT-PCR analysis of full-length HCII gene. Hepatic RNA was prepared with the use of TRIzOL reagent (Invitrogen), and conventional RT-PCR to detect $H C I I$ gene transcripts was performed as described previously (57). PCR primers were designed for the front side of the HCII gene (top of exon 1 to tail of exon 3): forward, 5'-CTGCCAGACCACTGCTCAGAGGTA-3', and reverse, $5^{\prime}$-CTGTTTGTCATGCTTTTTTGCC-3'; and the tail side of the HCII gene (top of exon 3 to tail of exon 5): forward, GAACTTGGGT-
GAATAAATTCCCAG-3' ${ }^{\prime}$, and reverse, $5^{\prime}$-CATGGTAAATATGGTTGTTTA$3^{\prime}$. The PCR conditions were 35 cycles of denaturation for 60 seconds at $94^{\circ} \mathrm{C}$, annealing for 60 seconds at $54^{\circ} \mathrm{C}$, and extension for 90 seconds at $72^{\circ} \mathrm{C}$. The WT allele of the front side of the HCII gene gave a 1,264-bp band, and that of the tail side of the HCII gene gave a 1,139-bp band.

Northern blot analysis. Approximately $20 \mu \mathrm{g}$ of total RNA of liver was fractionated on $1 \%$ formaldehyde-agarose gels and transferred to Hybond nylon membranes (GE Healthcare) by capillary action in high-salt solution (20x sodium chloride-sodium citrate). Blots were prehybridized in a hybridization solution for 1 hour at $42^{\circ} \mathrm{C}$, followed by overnight hybridization with digoxigenin-labeled specific oligonucleotide probes (DIG Northern Starter Kit; Roche Diagnostics) as described previously (57). HCII mRNAs were estimated after correction for loading differences by measuring the amount of 28S rRNA. The intensity of the bands was also measured using ImageJ 1.29 (http://rsb.info.nih.gov/ij/). The forward and reverse sequences of the $\mathrm{HCII}$ oligonucleotide probe were 5'-GAACTTGGGTGAATAAATTCCCAG-3' and 5'-CTGTTTGTCATGCTTTTTTGCC-3', respectively.

Western blot analysis. Hepatic tissue samples were homogenized in an ice-cold tissue protein extraction reagent (T-PER; Pierce) containing protease inhibitors. Equal amounts of protein $(50 \mu \mathrm{g})$ were loaded onto $10 \%$ acrylamide gels and then transferred to nitrocellulose membranes using a wet blot apparatus. Membranes were blocked overnight at $4^{\circ} \mathrm{C}$ in blocking buffer $(10 \mathrm{mM}$ Tris- $\mathrm{HCl}, 10 \mathrm{mM} \mathrm{NaCl}, 0.1 \%$ polyoxyethylenesorbitan monolaurate) with $5 \%$ skim milk. The first antibody, goat 
A
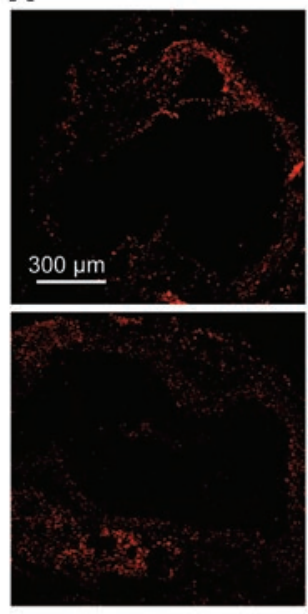

$\mathrm{HCII}^{++} \mathrm{apo} \mathrm{E}^{-/-}$
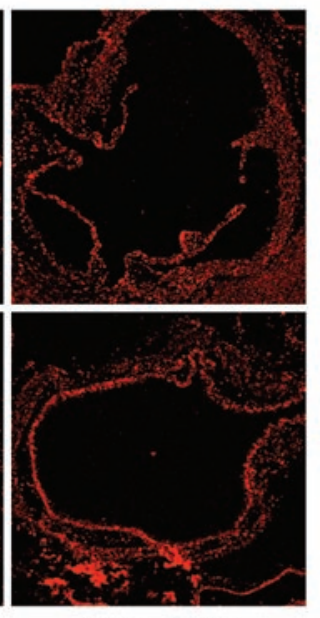

$\mathrm{HCII}^{+/}$-apoE $\mathrm{E}^{-/-}$
B

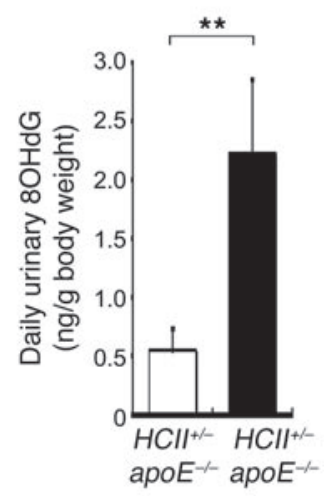

immediately sutured without cuff placement. Four weeks after the surgery, the mice were sacrificed with high-dose pentobarbital and perfused first with physiological saline and then with $10 \%$ neutral buffered formalin at $100 \mathrm{mmHg}$. Then the cuffed arteries and sham-operated arteries were removed with surrounding tissues.

Vascular injury by wire insertion into femoral arteries. Wire insertion surgery was performed on 16-week-old male mice as described previously (59). Either the left or right femoral artery was exposed by blunted dissection. A small branch between the rectus femoris and vastus medialis muscles was isolated and looped proximally and ligated distally with 6-0 silk sutures. Veins and connective tissues around the artery were removed. The exposed muscular branch artery was dilated by topical application of 1 drop of $1 \%$ lidocaine hydrochloride. Transverse arteriotomy was performed in the muscular branch with Vannas-style iris spring scissors (Fine Science Tools). A straight spring wire $(0.38 \mathrm{~mm}$ in diameter; no. C-SF-15-15; COOK Inc.) was inserted into the femoral artery for more than $5 \mathrm{~mm}$ toward the iliac artery. The wire was left in place for 1 minute to denude and dilate the artery. Then the wire was removed, and the silk suture looped at the proximal portion of the muscular branch artery was secured. Four weeks after the surgery, the mice were sacrificed with high-dose pentbarbital and perfused first with physiological saline and then with $10 \%$ neutral buffered for-

anti-human HCII antibody (1:1,000 dilution; Affinity Biologicals Inc.), was applied for 1 hour at room temperature. After a 30-minute wash with the blocking buffer, membranes were probed with the second antibody [1:5,000 dilution peroxidase-conjugated AffiniPure $F\left(a b^{\prime}\right)_{2}$ fragment rabbit anti-goat IgG antibody; Jackson ImmunoResearch Laboratories Inc.] for 1 hour at room temperature. Membranes were washed again for 30 minutes. The membranes were then incubated with chemiluminescent reagents (Amersham ECL Plus Western Blotting Detection System; GE Healthcare) for 5 minutes and then exposed to $x$-ray film. The band intensities were quantified using ImageJ 1.29.

Measurements of plasma HCII activities and hemostatic evaluations of murine plasma. Blood was drawn through a heart puncture and collected into a tube containing a 1:10 volume of $3.8 \%$ sodium citrate and then centrifuged at $2,000 \mathrm{~g}$ for 20 minutes. Plasma was stored at $-80^{\circ} \mathrm{C}$ until use. Plasma HCII activity was measured on the basis of antithrombin activity in the presence of DS, with the use of the STACHROM HCII colorimetric assay (Diagnostica Stago). HCII activity of pooled murine plasma of 16-week-old C57BL/6J mice (8 males) was set at $100 \%$. The intraassay and interassay coefficients of variation of this kit were $3.9 \%$ and $4.3 \%$, respectively (23, 24). Fibrinogen concentration was evaluated by Clauss's coagulometric technique, and prothrombin time and plasma AT activity were measured as described previously (57). Measurements of platelet aggregation with a screen filtration pressure aggregometer (WBA analyzer from SSR Engineering Co.) were performed according to a previously described method (57).

Measurements of plasma HCII antigen levels. Murine plasma HCII antigen levels were estimated by ELISA described previously as online supplemental data (http://atvb.ahajournals.org/cgi/content/full/25/12/2689/DC1; ref. 58).

Vascular injury by cuff placement around femoral arteries. Cuff placement surgery was carried out on 16-week-old male mice as described previously (48). In brief, the right femoral artery was isolated from surrounding tissues, and then a polyethylene tube (2-mm PE-50; inner diameter, $0.56 \mathrm{~mm}$; outer diameter, $0.965 \mathrm{~mm}$; BD) was cut longitudinally, loosely placed around the artery, and then closed with suture. At the same time, the left femoral artery was also isolated from surrounding tissues and

malin at $100 \mathrm{mmHg}$. Then the cuffed arteries and sham-operated arteries were removed with surrounding tissues.

Real-time PCR analysis. Hepatic tissues and cuffed arteries after 4 weeks of cuff placement and control intact arteries were perfused with physiological saline and then removed. RNA was prepared with the use of TRIzol reagent (Invitrogen), and real-time PCR was performed as described previously (60). PCR primers were designed for ubiquitin-conjugating enzyme E2L3 (Ube2l3), forward, $5^{\prime}$-TCCGTAACATCCAGGTTGATGAAG-3', and reverse, 5'-GGTTTGAATGGATACTCTGCTGGAA-3'; phosphatidylinositol 4kinase, catalytic, alpha polypeptide (Pik4ca), forward, $5^{\prime}$-AACCAGCAGTGTGTCCAGCATC-3', and reverse, $5^{\prime}$-CAGTCCCATCAGGTAGGCAAGAA-3'; synaptosomal-associated protein (Snap29), forward, 5'-GACAGGCAGCAGTACCTGAGACA-3', and reverse, 5'-GCTCATCTTCAAATCCTGATCCA-3'; Illb, forward, 5'-ATGGCAACTGTTCCTGAA-3', and reverse, 5'-GTACAAAGCTCATGGAGA- $3^{\prime}$; $I l 6$, forward, $5^{\prime}$-TTCCCTACTTCACAAGTC-3' ${ }^{\prime}$ and reverse, $5^{\prime}$-GGTTTGCCGAGTAGATCT-3'; Mcp1, forward, 5'-CCAACTCTCACTGAAGCCAGCTC-3', and reverse, 5'-TTGGGATCATCTTGCTGGTGAA-3'; Egr1, forward, 5'-CTATGAGCACCTGACCACA-3', and reverse, 5'-TAGTCAGGGATCATGGGAAC-3'; Klf5, forward, $5^{\prime}$-CTCCGGAGACGATCTGAAACAC- $3^{\prime}$, and reverse, $5^{\prime}$-CCACTGAGGCACTGTCTCGTCTA- $3^{\prime}$; and $\beta$-actin, forward, $5^{\prime}$-TGGAATCCTGTGGCATCCATGAAAC- $3^{\prime}$, and reverse, $5^{\prime}$-TAAAACGCAGCTCAGTAACAGTCCG-3'. Expression levels of Ube2l3, Pik4ca, Snap29, Il1b, Il6, Mcp1, Egr1, and Klf5 were expressed relative to $\beta$-actin signal.

Histological and immunohistochemical studies. The removed arterial tissues (aortic root, femoral arteries) were fixed in 10\% neutral buffered formalin overnight. The aortic root and middle segment of the femoral arteries were cut into subserial $5-\mu \mathrm{m}$-thick cross sections with intervals of $200 \mu \mathrm{m}$. Then sections were stained with Elastica-van Gieson (femoral arteries), Masson trichrome, and PAR-1 [Thrombin R (H-111):sc-5605; Santa Cruz Biotechnology Inc.] (aortic root). Antibody distribution was visualized by the avidin-biotin complex technique and Vector Red substrate (Vector Laboratories) (61). The average from 5 sections for each animal tissue was used to determine lesion size. 
Detection of proliferative cells by BrdU and PCNA staining. BrdU $(100 \mathrm{mg} / \mathrm{kg}$ in saline) was injected intraperitoneally, and the mice were perfused 6 hours later with $10 \%$ neutral buffered formalin; then their femoral arteries were fixed in $10 \%$ neutral buffered formalin in PBS. Immunohistochemical staining was performed using a Cell Proliferation Kit (GE Healthcare) according to the instructions of the manufacturer. For immunohistochemistry, sections were fixed in $10 \%$ neutral buffered formalin for 10 minutes at room temperature, embedded in paraffin, sectioned at $2 \mu \mathrm{m}$, and counterstained with hematoxylin. Labeled cells and total cells in the intima and media were counted in all sections per specimen, and labeling indices were calculated as the labeled cell/total cell ratio of intima and media.

Human purified HCII protein administration in cuff-injured or wire-injured HCII mutant mice. Human HCII protein was purified by a heparin affinity column from human pooled plasma as previously reported (62) and buffered with $10 \mathrm{mM}$ sodium phosphate and 5\% sorbitol. Because heparin was covalently bound to this column bed, no elution of heparin was observed. The purity of HCII protein measured by HPLC was more than $99 \%$. We first measured the time course of plasma HCII activities in $\mathrm{HCII}^{+/-}$mice after intraperitoneal injection of human purified HCII protein $(45 \mathrm{mg} / \mathrm{kg}$ ) or vehicle alone. Then cuff-injured or wire-injured WT mice and 1 group of $\mathrm{HCII}^{+/-}$mice were injected with the vehicle intraperitoneally 3 times per week for 4 weeks, while another group of cuff-injured or wire-injured $\mathrm{HCII}^{+/-}$mice were injected with purified human HCII protein $(45 \mathrm{mg} / \mathrm{kg})$ intraperitoneally 3 times per week for 4 weeks. Cuff-injured or wire-injured arteries in these mice were removed and used for histological evaluation by Elastica-van Gieson staining.

Superoxide detection and oil red $O$ staining in the aortic root. The aortic root and ascending aorta were excised from mice, rinsed in normal saline, and frozen in optimal cutting temperature compound (Tissue-Tek; Sakura Finetek) until use. Transverse sections (10 $\mu \mathrm{m}$ thick) were cut with a cryostat and placed on silane-coated glass slides. Oil red O staining was performed as described previously (63). The slide glasses were incubated with DHE in PBS $(10 \mu \mathrm{mol} / \mathrm{l})$ in a dark, humidified container at room temperature for 30 minutes. DHE is oxidized on reaction with superoxide to ethidium bromide, which binds to DNA in the nucleus and fluoresces red. After placement of cover glass, aortic tissues were observed using a laser scanning confocal microscope (Nikon Digital Eclipse CFI-Ready). The excitation wavelength was $488 \mathrm{~nm}$, and emission fluorescence was detected with a 568-nm long-pass filter.

Measurement of urinary $8 \mathrm{OHd}$ excretion. To evaluate urinary excretion of $8 \mathrm{OHdG}$, as an oxidative DNA damage marker, mice were individually housed in metabolic cages that provided free access to tap water and food for 24 hours, and collected urine was analyzed using a commercially available ELISA assay kit (Nikken SEIL Corp.). The amount of urinary $8 \mathrm{OHdG}$ excretion was corrected to the volume of urine in a given day and body weight $(\mathrm{g})$.

Statistics. Values for parameters within a group are expressed as mean \pm SEM. For comparisons among groups, statistical significance was assessed using an unpaired 2-tailed Student's $t$ test or 1-way ANOVA, and the significance of each difference was determined by post-hoc testing using the Tukey-Kramer method. These analyses were performed on an Apple Macintosh computer with the use of Excel (Microsoft) and StatView statistical package (StatView 5.0; SAS Institute Inc.). A $P$ value of less than 0.05 was considered significant.

\section{Acknowledgments}

This work was supported in part by Grants-in-Aid for Scientific Research and a grant for the 21st Century Center of Excellence Program from the Ministry of Education, Science, Sports, and Culture of Japan; a grant for a Study Group on Aseptic Femoral Neck Necrosis from the Ministry of Health, Labor, and Welfare of Japan; and grants from the Japan Medical Association, Mitsubishi Pharma Research Foundation, and The Uehara Memorial Foundation, and a grant for clinical vascular function from the Kimura Memorial Cardiovascular Foundation. We thank Kazue Ishikawa of the University of Tokushima and Hiromi Kato of the University of Tokyo for their expert technical assistance. We also thank Douglas M. Tollefsen of Washington University for providing us with $\mathrm{HCII}^{+/-}$St. Louis mice and sharing their unpublished data on vascular remodeling in HCII-deficient St. Louis mice. We are grateful to Tusar K. Giri of Washington University in St. Louis for measuring murine plasma HCII antigen levels.

Received for publication October 10, 2005, and accepted in revised form March 27, 2007.

Address correspondence to: Toshio Matsumoto, Department of Medicine and Bioregulatory Sciences, The University of Tokushima Graduate School of Health Biosciences, 3-18-15 Kuramotocho, Tokushima 770-8503, Japan. Phone: 81-88-633-7119; Fax: 81-88-633-7407; E-mail: toshimat@clin.med.tokushima-u.ac.jp.
1. Narayanan, S. 1999. Multifunctional roles of thrombin. Ann. Clin. Lab Sci. 29:275-280.

2. Bar-Shavit, R., Kahn, A., Wilner, G.D., and Fenton, J.W., 2nd. 1983. Monocyte chemotaxis: stimulation by specific exosite region in thrombin. Science. 220:728-731.

3. Chen, L.B., and Buchanan, J.M. 1975. Mitogenic activity of blood components. I. Thrombin and prothrombin. Proc. Natl. Acad. Sci. U. S. A. 72:131-135.

4. McNamara, C.A., et al. 1993. Thrombin stimulates proliferation of cultured rat aortic smooth muscle cells by a proteolytically activated receptor. J. Clin. Invest. 91:94-98.

5. Derian, C.K., Damiano, B.P., D'Andrea, M.R., and Andrade-Gordon, P. 2002. Thrombin regulation of cell function through protease-activated receptors: implications for therapeutic intervention. Biochemistry Mosc. 67:56-64.

6. Griffin, C.T., Srinivasan, Y., Zheng, Y.W., Huang, W., and Coughlin, S.R. 2001. A role for thrombin receptor signaling in endothelial cells during embryonic development. Science. 293:1666-1670.

7. Cheung, W.M., D'Andrea, M.R., Andrade-Gordon, P., and Damiano, B.P. 1999. Altered vascular injury responses in mice deficient in proteaseactivated receptor-1. Arterioscler. Thromb. Vasc. Biol.
19:3014-3024.

8. Nelken, N.A., et al. 1992. Thrombin receptor expression in normal and atherosclerotic human arteries. J. Clin. Invest. 90:1614-1621.

9. Sambrano, G.R., Weiss, E.J., Zheng, Y.W., Huang, W., and Coughlin, S.R. 2001. Role of thrombin signalling in platelets in haemostasis and thrombosis. Nature. 413:74-78.

10. Major, C.D., Santulli, R.J., Derian, C.K., and Andrade-Gordon, P. 2003. Extracellular mediators in atherosclerosis and thrombosis: lessons from thrombin receptor knockout mice. Arterioscler. Thromb. Vasc. Biol. 23:931-939.

11. Hirano, K., and Kanaide, H. 2003. Role of proteaseactivated receptors in the vascular system. J. Atheroscler. Thromb. 10:211-225.

12. Singh, R., et al. 2001. Role for tissue factor pathway in murine model of vascular remodeling. Circ. Res. 89:71-76.

13. Li, Y.H., et al. 2006. Thrombomodulin plays an important role in arterial remodeling and neointima formation in mouse carotid ligation model. Thromb. Haemost. 95:128-133.

14. Peng, L., Bhatia, N., Parker, A.C., Zhu, Y., and Fay, W.P. 2002. Endogenous vitronectin and plasminogen activator inhibitor-1 promote neointima formation in murine carotid arteries. Arterioscler. Thromb. Vasc. Biol. 22:934-939.

15. Gerdes, C., Faber-Steinfeld, V., Yalkinoglu, O., and Wohlfeil, S. 1996. Comparison of the effects of the thrombin inhibitor r-hirudin in four animal models of neointima formation after arterial injury. Arterioscler. Thromb. Vasc. Biol. 16:1306-1311.

16. de Agostini, A.I., Watkins, S.C., Slayter, H.S., Youssoufian, H., and Rosenberg, R.D. 1990. Localization of anticoagulantly active heparan sulfate proteoglycans in vascular endothelium: antithrombin binding on cultured endothelial cells and perfused rat aorta. J. Cell Biol. 111:1293-1304.

17. Tollefsen, D.M., Pestka, C.A., and Monafo, W.J. 1983. Activation of heparin cofactor II by dermatan sulfate. J. Biol. Chem. 258:6713-6716.

18. Tollefsen, D.M. 1995. Insight into the mechanism of action of heparin cofactor II. Thromb. Haemost. 74:1209-1214.

19. Rosenberg, L.C., et al. 1985. Isolation of dermatan sulfate proteoglycans from mature bovine articular cartilages. J. Biol. Chem. 260:6304-6313.

20. Choi, H.U., et al. 1989. Characterization of the dermatan sulfate proteoglycans, DS-PGI and DS-PGII, from bovine articular cartilage and skin isolated by octyl-sepharose chromatography. J. Biol. Chem. 
264:2876-2884.

21. Shirk, R.A., Parthasarathy, N., San Antonio, J.D. Church, F.C., and Wagner, W.D. 2000. Altered dermatan sulfate structure and reduced heparin cofactor II-stimulating activity of biglycan and decorin from human atherosclerotic plaque. J. Biol. Chem. 275:18085-18092.

22. Kanagawa, Y., et al. 2001. Molecular mechanism of type I congenital heparin cofactor (HC) II deficiency caused by a missense mutation at reactive $\mathrm{P} 2$ site: HC II Tokushima. Thromb. Haemost. 85:101-107.

23. Takamori, N., et al. 2004. High plasma heparin cofactor II activity is associated with reduced incidence of in-stent restenosis after percutaneous coronary intervention. Circulation. 109:481-486.

24. Aihara, K., et al. 2004. Heparin cofactor II is a novel protective factor against carotid atherosclerosis in elderly individuals. Circulation. 109:2761-2765.

25. He, L., Vicente, C.P., Westrick, R.J., Eitzman, D.T., and Tollefsen, D.M. 2002. Heparin cofactor II inhibits arterial thrombosis after endothelial injury. J. Clin. Invest. 109:213-219. doi:10.1172/ JCI200213432.

26. Wilcox,J.N., et al. 1994. Characterization of thrombin receptor expression during vascular lesion formation. Circ. Res. 75:1029-1038.

27. Takada, M., et al. 1998. Antibody to thrombin receptor inhibits neointimal smooth muscle cell accumulation without causing inhibition of platelet aggregation or altering hemostatic parameters after angioplasty in rat. Circ. Res. 82:980-987.

28. Andrade-Gordon, P., et al. 2001. Administration of a potent antagonist of protease-activated receptor-1 (PAR-1) attenuates vascular restenosis following balloon angioplasty in rats. J. Pharmacol. Exp. Ther. 298:34-42.

29. Sata, M., et al. 2002. Hematopoietic stem cells differentiate into vascular cells that participate in the pathogenesis of atherosclerosis. Nat. Med. 8:403-409.

30. Gutierrez, J., Ballinger, S.W., Darley-Usmar, V.M., and Landar, A. 2006. Free radicals, mitochondria, and oxidized lipids: the emerging role in signal transduction in vascular cells. Circ. Res. 99:924-932.

31. Kamp, P.B., and Ragg, H. 1999. Rapid changes in the exon/intron structure of a mammalian thrombin inhibitor gene. Gene. 229:137-144.

32. Villa, P., et al. 1999. Hereditary homozygous heparin cofactor II deficiency and the risk of developing venous thrombosis. Thromb. Haemost. 82:1011-1014.

33. Corral, J., et al. 2004. Homozygous deficiency of heparin cofactor II: relevance of P17 glutamate residue in serpins, relationship with conformational diseases, and role in thrombosis. Circulation. 110:1303-1307.
34. Delorme, M.A., Xu, L., Berry, L., Mitchell, L., and Andrew, M. 1998. Anticoagulant dermatan sulfate proteoglycan (decorin) in the term human placenta. Thromb. Res. 90:147-153.

35. Bellart, J., et al. 1998. Heparin cofactor II: a new marker for pre-eclampsia. Blood Coagul. Fibrinolysis. 9:205-208.

36. Giri, T.K., and Tollefsen, D.M. 2006. Placental dermatan sulfate: isolation, anticoagulant activity, and association with heparin cofactor II. Blood. 107:2753-2758.

37. Tollefsen, D.M. 2002. Heparin cofactor II deficiency. Arch. Pathol. Lab. Med. 126:1394-1400.

38. Tollefsen, D.M. 2004. Does heparin cofactor II modulate atherosclerosis and restenosis? Circulation. 109:2682-2684.

39. Schillinger, M., et al. 2004. High plasma heparin cofactor II activity protects from restenosis after femoropopliteal stenting. Thromb. Haemost. 92:1108-1113

40. Vu, T.K., Hung, D.T., Wheaton, V.I., and Coughlin, S.R. 1991. Molecular cloning of a functional thrombin receptor reveals a novel proteolytic mechanism of receptor activation. Cell. 64:1057-1068.

41. Ishihara, H., et al. 1997. Protease-activated receptor 3 is a second thrombin receptor in humans. Nature. 386:502-506

42. Xu, W.F., et al. 1998. Cloning and characterization of human protease-activated receptor 4. Proc. Natl. Acad. Sci. U. S. A. 95:6642-6646.

43. Patterson, C., et al. 1999. Stimulation of a vascular smooth muscle cell NAD(P)H oxidase by thrombin. Evidence that p47(phox) may participate in forming this oxidase in vitro and in vivo. J. Biol. Chem. 274:19814-19822.

44. Kalmes, A., Vesti, B.R., Daum, G., Abraham, J.A. and Clowes, A.W. 2000. Heparin blockade of thrombin-induced smooth muscle cell migration involves inhibition of epidermal growth factor (EGF) receptor transactivation by heparin-binding EGF-like growth factor. Circ. Res. 87:92-98.

45. Takeya, H., Gabazza, E.C., Aoki, S., Ueno, H., and Suzuki, K. 2003. Synergistic effect of sphingosine 1phosphate on thrombin-induced tissue factor expression in endothelial cells. Blood. 102:1693-1700

46. Hoshi, S., Goto, M., Koyama, N., Nomoto, K., and Tanaka, H. 2000. Regulation of vascular smooth muscle cell proliferation by nuclear factor-kappaB and its inhibitor, I-kappaB. J. Biol. Chem. 275:883-889.

47. Dinarello, C.A. 1996. Biologic basis for interleukin-1 in disease. Blood. 87:2095-2147.

48. Shindo, T., et al. 2002. Kruppel-like zinc-finger transcription factor KLF5/BTEB2 is a target for angiotensin II signaling and an essential regulator of cardiovascular remodeling. Nat. Med. 8:856-863. 49. Loppnow, H., and Libby, P. 1990. Proliferating or interleukin 1-activated human vascular smooth muscle cells secrete copious interleukin 6. J. Clin. Invest. 85:731-738.

50. Spinetti, G., et al. 2004. Rat aortic MCP-1 and its receptor CCR2 increase with age and alter vascular smooth muscle cell function. Arterioscler. Thromb. Vasc. Biol. 24:1397-1402.

51. Isoda, K., et al. 2003. Deficiency of interleukin-1 receptor antagonist promotes neointimal formation after injury. Circulation. 108:516-518.

52. Yoshizawa, T., et al. 1997. Mice lacking the vitamin D receptor exhibit impaired bone formation, uterine hypoplasia and growth retardation after weaning. Nat. Genet. 16:391-396.

53. Sekine, K., et al. 1999. Fgf10 is essential for limb and lung formation. Nat. Genet. 21:138-141.

54. Kawano, H., et al. 2003. Suppressive function of androgen receptor in bone resorption. Proc. Natl. Acad. Sci. U. S. A. 100:9416-9421.

55. Nakamichi, Y., et al. 2003. Chondromodulin I is a bone remodeling factor. Mol. Cell. Biol. 23:636-644.

56. Matsuda, Y., et al. 1992. Location of the mouse complement factor $\mathrm{H}$ gene (cfh) by FISH analysis and replication R-banding. Cytogenet. Cell Genet. 61:282-285.

57. Aihara, K., et al. 2004. Disruption of nuclear vitamin D receptor gene causes enhanced thrombogenicity in mice. J. Biol. Chem. 279:35798-35802.

58. Giri, T.K., Ahn, C.W., Wu, K.K., and Tollefsen, D.M. 2005. Heparin cofactor II levels do not predict the development of coronary heart disease: the Atherosclerosis Risk in Communities (ARIC) study. Arterioscler. Thromb. Vasc. Biol. 25:2689-2690.

59. Sata, M., et al. 2000. A mouse model of vascular injury that induces rapid onset of medial cell apoptosis followed by reproducible neointimal hyperplasia. J. Mol. Cell. Cardiol. 32:2097-2104.

60. Ikeda, Y., et al. 2005. Androgen receptor gene knockout male mice exhibit impaired cardiac growth and exacerbation of angiotensin II-induced cardiac fibrosis. J. Biol. Chem. 280:29661-29666.

61. Sata, M., Tanaka, K., Ishizaka, N., Hirata, Y., and Nagai, R. 2003. Absence of p53 leads to accelerated neointimal hyperplasia after vascular injury. Arterioscler. Thromb. Vasc. Biol. 23:1548-1552.

62. Yamanaga, K., et al. 2000. Heparin cofactor II inhibits thrombus formation in a rat thrombosis model. Thromb. Res. 98:95-101.

63. Zhou, J., Lhotak, S., Hilditch, B.A., and Austin, R.C. 2005. Activation of the unfolded protein response occurs at all stages of atherosclerotic lesion development in apolipoprotein E-deficient mice. Circulation. 111:1814-1821 